\title{
International approaches to rural generalist medicine: a scoping review
}

Nicholas Schubert ${ }^{*}$ D, Rebecca Evans², Kristine Battye ${ }^{3}$, Tarun Sen Gupta², Sarah Larkins ${ }^{2}$ and Lachlan Mclver ${ }^{4}$

\begin{abstract} systematic research in this area.

Important themes emerging from the review were:

- Definition

- Existing pathways and programmes

- Scope of practice and service models

- Enablers and barriers to recruitment and retention

- Reform recommendations
\end{abstract}

Background: Contemporary approaches to rural generalist medicine training and models of care are developing internationally as part of an integrated response to common challenges faced by rural and remote health services and policymakers (addressing health inequities, workforce shortages, service sustainability concerns). The aim of this study was to review the literature relevant to rural generalist medicine.

Methods: A scoping review was undertaken to answer the broad question 'What is documented on rural generalist medicine?' Literature from January 1988 to April 2017 was searched and, after final eligibility filtering (according to established inclusion and exclusion criteria), 102 articles in English language were included for final analysis.

Results: Included papers were analysed and categorised by geographic region, study design and subject themes. The majority of articles (80\%) came from Australia/New Zealand and North America, reflecting the relative maturity of programmes supporting rural generalist medicine in those countries. The most common publication type was descriptive opinion pieces (37\%), highlighting both a need and an opportunity to undertake and publish more

There were some variations to, or criticisms of, the definition of rural generalist medicine as applied to this review, although this was only true of a small number of included articles. Across remaining themes, there were many similarities and consistent approaches to rural generalist medicine between countries, with some variations reflecting environmental context and programme maturity. This review identified recent literature from countries with emerging interest in rural generalist medicine in response to problematic rural health service delivery.

Conclusions: Supported, coordinated rural generalist medicine programmes are being established or developed in a number of countries as part of an integrated response to rural health and workforce concerns. Findings of this review highlight an opportunity to better share the development and evaluation of best practice models in rural generalist medicine.

Keywords: Rural, Remote, Medicine, Generalism, Primary health care

\footnotetext{
* Correspondence: nick.schubert1@my.jcu.edu.au

James Cook University, Townsville, Australia

Full list of author information is available at the end of the article
}

(c) The Author(s). 2018 Open Access This article is distributed under the terms of the Creative Commons Attribution 4.0 International License (http://creativecommons.org/licenses/by/4.0/), which permits unrestricted use, distribution, and reproduction in any medium, provided you give appropriate credit to the original author(s) and the source, provide a link to the Creative Commons license, and indicate if changes were made. The Creative Commons Public Domain Dedication waiver (http://creativecommons.org/publicdomain/zero/1.0/) applies to the data made available in this article, unless otherwise stated. 


\section{Background}

A rural generalist, for the purpose of this review, is defined as a community physician, primary care physician, general practitioner (GP), or family practitioner/family physician, with 'recognised skill sets and qualifications, credentialed to provide primary care, hospital, emergency and population health care as well as one or more areas of advanced specialised practice in a rural, remote and/or regional setting' [1]. This definition is consistent with the Cairns Consensus Statement (May 2014), an international document defining rural generalist medicine (RGM) and its key pillars and supported by representatives of the First World Summit on Rural Generalist Medicine in 2013. The Cairns Consensus Statement describes RGM as 'the provision of a broad scope of medical care by a doctor in the rural context that encompasses the following:

- Comprehensive primary care for individuals, families and communities;

- Hospital in-patient and/or related secondary medical care in the institutional, home or ambulatory setting;

- Emergency care;

- Extended and evolving service in one or more areas of focused cognitive and/or procedural practice as required to sustain needed health services locally among a network of colleagues;

- A population health approach that is relevant to the community;

- Working as part of a multi-professional and multidisciplinary team of colleagues, both local and distant, to provide services within a 'system of care' that is aligned and responsive to community needs' [2].

Contemporary RGM must be considered against a backdrop of challenges faced by policymakers, health services and medical educators in addressing ongoing health inequities [3], workforce shortages [4] and service sustainability concerns specific to rural and remote areas around the world [5, 6]. These challenges reflect the paradox of the 'inverse care law' and the inequity of access to health care in areas of most need; in this case rural and remote communities [7]. More recently, a number of countries have investigated RGM as part of an integrated solution to these issues, including supported pathways aimed at developing a rural medical workforce skilled in primary health care, public health and advanced specialist care $[1,8]$. This emerging international focus on RGM is highlighted by three RGM World Summits since 2013; now a biennial event $[2,9]$.

RGM has been a feature of medicine in countries with large rural and/or remote areas for a considerable time $[8,10]$, despite variations in rural generalist titles, nature of training programmes and models of care. However, the commitment to coordinated RGM training is now occurring in a climate of generalist practitioner shortages [11], most prevalent in rural communities and areas of socio-economic disadvantage [12-15]. Rural workforce shortages have been identified by the World Health Organization (WHO) as a significant barrier to universal, equitable health coverage [16]. Some of the common drivers for these shortages include the increasing trend toward metropolitan-based medical specialisation [17]; feminisation and ageing of the medical workforce; changing work priorities of younger doctors; changing attitudes toward owning a general practice; and, negative perceptions of both rural and general practice $[18,19]$.

This scoping review aims to capture, analyse and summarise the international state of knowledge relevant to the development and support of RGM training, models of care and clinical practice.

\section{Methods}

The question 'what is documented on rural generalist medicine?' ensured that a broad range of literature was captured in this review. Broad analysis of the scale and scope of available literature is consistent with scoping review methodology and the five stage framework developed by Arksey and O'Malley: establishing the research question, identifying relevant studies, selecting studies to be included, charting data and summarising results [20].

Inclusion and exclusion criteria (Table 1) focused the search results to ensure relevance of findings. Government and education policies aimed at addressing the geographic maldistribution of the medical workforce took a significant shift from the late 1980s and continued during the 1990s [19, 21, 22]. To capture this change, literature from January 1988 to April 2017 was sourced and reviewed.

Medical subject headings $(\mathrm{MeSH})$ and Boolean operators were used to narrow, widen and combine literature searches and ensure relevant literature was captured in the search Table 2). This search was supplemented by bibliographic searching and inclusion of grey literature.

Using these parameters, 2454 articles were initially retrieved in the database searches. The variation in titles and terms within the RGM field may have had some influence on the search results. However, after selecting the relevant articles based on inclusion criteria (Table 1) and removing duplicates, 140 articles were retained for review (Fig. 1). A further 36 articles were identified using Google Scholar. Grey literature obtained through data searches and prior knowledge added another 39 articles (this included 11 websites). A further 17 articles were included as a result of bibliographic searching. Three more articles were included as a result of manual journal searches. Guided by the inclusion and exclusion criteria, a total of 235 studies were identified as relevant to the research topic. 
Table 1 The inclusion/exclusion criteria applied to the screening of the papers for this review

\begin{tabular}{lll}
\hline Criterion & Inclusion & Exclusion \\
\hline Time period & January 1988 to April 2017 & Studies outside of these dates \\
Language & English & Non-English studies \\
Type of article & No limits were placed on the literature type & N/A \\
Study focus & Rural medical generalism: the definition and & Articles on rural generalism that did not \\
& scope of rural medical generalists, the RMG & meet the specific definition of this paper \\
& training pathway, enablers and barriers to & Disciplines outside of medicine (allied health, \\
& Rural generalism definition as general & nursing and health support roles) \\
& practitioner/family practitioner/family & Rural specialist physicians including 'generalist \\
physician in rural areas with reference & specialists' \\
& to provision of primary and emergency & Articles with a focus only on a specific advanced \\
care and one or more specialised practice & contlext obstetrics) unless it was examined in the \\
& The definition of rural generalist medicine & Disease specific research
\end{tabular}

Literature focus Articles with specific reference to the development of rural medical generalism and/or rurally based general practitioners, family practitioners, primary health medical practitioners or family physicians with specialised (procedural or non-procedural) skills

Population and sample
Rurally based medical generalists as rural GPs/primary medical care providers with specialised skills (including rural GP proceduralists)
Articles that discussed rural health, rural medicine and/or rural GPs but without reference to rural medical generalism as defined here

Other GPs and/or medical practitioners outside of the definition of rural medical generalist
During the final article selection, more were excluded on the grounds of relevance. In some cases, these articles did focus on 'generalism' but not rurality; others focused on the rural health workforce but without reference to generalism as defined in this review (Fig. 1). After final eligibility filtering, 102 articles were included in this review (Fig. 1 and Table 3). Another author reviewed all articles for consensus on inclusion.

\section{Results}

Articles included for the final review were identified by geographic origins to enable a comparative analysis of rural generalist medicine data by region (Table 4).

Articles were also identified by type of article or design (some were combined approaches, explaining the total

Table 2 Search terms and databases greater than 102; Table 5). The majority were descriptive opinion articles.

Table 6 contains a summary of each article by region, including the main findings. Data extracted from the articles was coded into key themes, including:

- Definition of rural generalism

- Existing pathways and programmes

- Scopes of practice and service models

- Enablers and barriers to recruitment and retention

- Reform Recommendations

The key findings in each theme are summarised below.

\section{Definition}

The majority of data relevant to the definition of RGM comes from Australia, reflecting a growth of coordinated RGM pathways since 2005. Early developments include

Table 3 Sources of retrieved and included papers

\begin{tabular}{lll}
\hline Source & Retrieved & Included \\
\hline Databases (MEDLINE, CINAHL, Informit & 140 & 44 \\
Health, EMBASE and PubMed) & & \\
Google Scholar & 36 & 20 \\
Grey Literature & 39 & 24 \\
Snowballing & 17 & 14 \\
Journal searches & 3 & 0 \\
Total & 235 & 102 \\
\hline
\end{tabular}




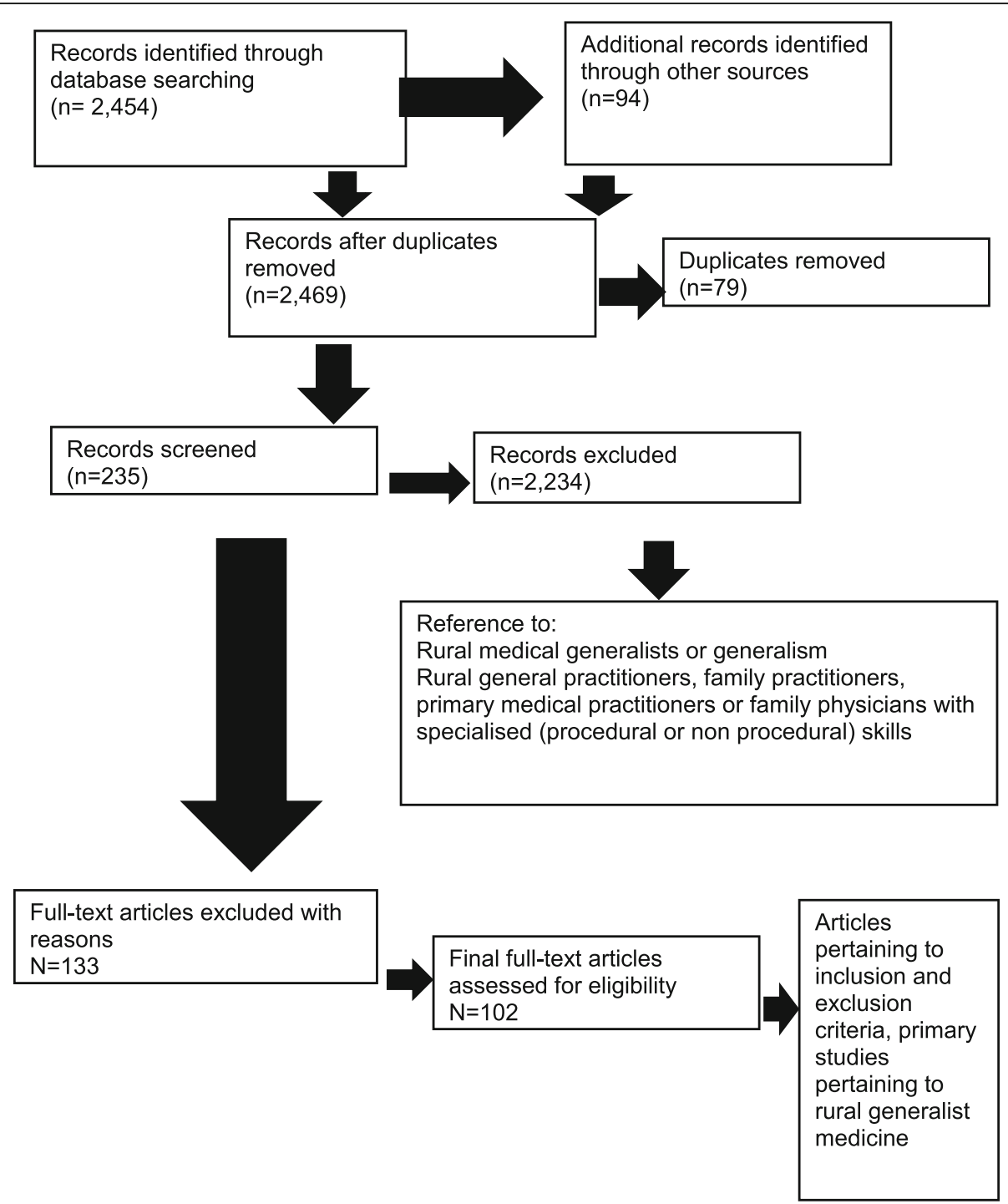

Fig. 1 Overview of the review process

the Roma Agreement [23], which underpinned the establishment of the 'Queensland Rural Generalist Pathway' (QRGP), an initiative of the state health department [24]. Similar definitions are now found in the literature used by the Australian College for Rural and Remote Medicine

Table 4 Geographic regions of included papers

\begin{tabular}{ll}
\hline Region & Included \\
\hline Asia Pacific & 4 \\
Australia/New Zealand & 46 \\
North America & 36 \\
Africa & 11 \\
Europe & 4 \\
International (WHO) & 1 \\
Total & 102 \\
\hline
\end{tabular}

Table $\mathbf{5}$ Articles by report type

\begin{tabular}{ll}
\hline Report type & Article numbers \\
\hline Descriptive opinion piece & 40 \\
Quantitative data analysis & 22 \\
Qualitative study (e.g. interviews/focus groups) & 12 \\
Position paper & 10 \\
Literature review & 8 \\
Programme description & 8 \\
Government report & 7 \\
Systematic review & 2 \\
Total & 109 \\
\hline
\end{tabular}


Table 6 Summary of included papers by region

\begin{tabular}{|c|c|c|c|}
\hline Author (citation number) & Location & Year & Study design/methods/sampl \\
\hline \multicolumn{4}{|l|}{ Asia Pacific } \\
\hline Basnyat [101] & Nepal & 2013 & Descriptive opinion piece \\
\hline Matsumoto et al. [98] & Japan & 2005 & Quantitative study_-survey \\
\hline
\end{tabular}

Findings/critique

Mavalankar et al. [102]

India

Moore [100]

Nepal

2006

Descriptive opinion piece

Australia/New Zealand

ACRRM [76]

Australia

ACRRM [86]

Australia

2002

ACRRM [25]

Australia

Position paper

ACRRM [2]
Position paper

Literature review and quantitative study — survey
- Outlines main emergency procedures of working in Kalikot District Hospital, including surgery and obstetrics procedures required of the primary care doctors and the resource limitations that they face.

- From this survey the only factor relevant to training identified as 'retention enhancing' has been

family medicine training.

- Authors advocate for an identified rural generalist practitioner training programme with a broad skill base with identified advanced skills (e.g. internal medicine, gastroenterology, general surgery). Obstetrics in rural Japan are however covered by specialists.

- Shortage of anaesthetists in India_especially in rural areas-and the programme developed to train MOs in LSAS. Highlighted protectionist opposition to the programme.

- 14 surveyed reported the practical training was too short. 5 felt that the training had not sufficiently prepared them. Training programme duration should be extended and that more time spent on practical areas.

- Overview of critical health needs in Nepal

- Highlights the need for a generalist workforce specific to Nepal, especially in subsistence farmland areas.

- Outlines a decline in the rural procedural workforce and the barriers to practise that have impacted on this decline.

- Provides recommendations to address the barriers to procedural practice outlined in the research report.

- Identifies key issues, enablers and barriers to establishing streamlined training and education for a career in Rural Generalist Medicine.

- Proposes a national officer position within the Commonwealth Department be established to oversee the integration of national RG pathway.

Also has 28 Recommendations for reform to build and support the RG pathway.

- Statement with international endorsement of a definition and recommendations for rural generalist medicine. The definition provided involves an integrated 
Table 6 Summary of included papers by region (Continued)

\begin{tabular}{llll}
\hline Author (citation number) & Location & Year & Study design/m \\
\hline & & & \\
ACRRM, RDAA and ARRWAG [103] & Australia & 2002 & Position paper \\
AMA [104] & Australia & 2012 & Position paper \\
AMA [105] & & & \\
& Australia & 2014 & Position paper
\end{tabular}

Descriptive opinion piece

Department of Health and Human Services, Tasmania [51]

Department of Health Victoria [28]

Ellis and Philip [84]

Glazebrook and Harrison [75]

Government of South Australia: SA Health [107]

Hays et al. [108]
Australia

Australia

Australia

Australia

Australia
Web link 2016 Programme description

Web link 2016 Programme description

2005
Government report

Descriptive opinion piece

Literature review

Qualitative study—interviews
Findings/critique

model of both primary

and secondary care and

recommendations are

provided under the domains

of Recognition, Training

Pathways and Research.

- Provides recommendations

to governments on key rural

generalist reform areas.

- Supports enhanced generalist pathways and greater recognition, including RGs.

- Regional Training Networks needed to establish expanded generalist and specialist post graduate training positions in regional/rural areas. At present Rural Generalist and Specialist

Training programmes are the only supported programmes addressing regional long-term placement in postgraduate medical training.

- Consider cooperative models of remote (surgical) specialist delivery in the Northern Territory, delivered by appropriately trained generalists in cooperation with and supported by specialists from larger areas.

- Overview of Tasmanian RG pathway and describes the RMG as 'a medical practitioner who is trained, mentored and supported on a 'career superhighway'.

- Provides a definition of a RG and characteristics of the Victorian RG programme.

- Describes the need for priority up-skilling generalist clinicians to meet the needs of clients facing mental health emergencies in rural and remote areas.

- Proposes the use of the 'Mental Health Emergencies' training programme developed by the Australian Rural Nurses and Midwives based on the success of this programme.

- Identifies the barriers to the maintenance of advanced procedural skills for rural generalists.

- Highlights AST training support for GPs in anaesthetics and obstetrics.

- The analysis highlights the differing views between health professionals and rural patients on the quality of care in rural hospitals. 
Table 6 Summary of included papers by region (Continued)

\begin{tabular}{|c|c|c|c|c|}
\hline Author (citation number) & Location & Year & Study design/methods/sample & Findings/critique \\
\hline & & & & $\begin{array}{l}\text { - Patients and families focussed on } \\
\text { interpersonal skills whereas } \\
\text { health professionals focussed } \\
\text { on workforce and technical } \\
\text { aspects of care. } \\
\text { - All groups agreed on the } \\
\text { need to be able to continue } \\
\text { to provide the flexible care and } \\
\text { familiar surrounds offered by } \\
\text { proceduralists in small rural } \\
\text { hospitals. } \\
\text { - This study indicates the } \\
\text { ongoing need for rural health } \\
\text { professionals to be trained in } \\
\text { providing procedural medical } \\
\text { care in smaller rural hospitals, } \\
\text { despite the developing trend } \\
\text { to centralise procedural tasks } \\
\text { in larger urban areas. }\end{array}$ \\
\hline $\begin{array}{l}\text { Health Education and Training } \\
\text { Institute (HETI) [26] }\end{array}$ & Australia & Web link 2016 & Programme description & $\begin{array}{l}\text { - Provides definition and overview } \\
\text { of the NSW RG pathway. } \\
\text { - Supported advanced skills are } \\
\text { anaesthetics, obstetrics and } \\
\text { 'advanced skill set' (Obstetrics } \\
\text { and Emergency Medicine). }\end{array}$ \\
\hline HWA [109] & Australia & 2012 & Government report & $\begin{array}{l}\text { - Overview of the imbalance in } \\
\text { the distribution of the specialist } \\
\text { vs generalist medical workforce. } \\
\text { - Identifies concerns about the } \\
\text { decline in generalists and impact } \\
\text { of rural workforce. } \\
\text { - Also identifies the geographic } \\
\text { maldistribution across the total } \\
\text { medical specialties including } \\
\text { general practice. }\end{array}$ \\
\hline HWA [1] & Australia & 2013 & Government report & $\begin{array}{l}\text { - Background to the need to focus } \\
\text { on supporting the RMG pathway. } \\
\text { Reform recommendations across } \\
\text { six domains. }\end{array}$ \\
\hline HWA [77] & Australia & 2014 & Quantitative study—survey & $\begin{array}{l}\text { - Shows that over half GP } \\
\text { proceduralists in rural Victoria } \\
\text { are not using their procedural } \\
\text { skills and } 32 \% \text { plan to retire in } \\
\text { the next } 5 \text { years. Identifies key } \\
\text { barriers to practise. }\end{array}$ \\
\hline Humphreys et al. [67] & Australia & 2003 & Quantitative study_-survey & $\begin{array}{l}\text { - Finds that the proportion of } \\
\text { GPs providing complex services } \\
\text { increases with increasing rurality } \\
\text { or remoteness. }\end{array}$ \\
\hline Jones [65] & Australia & 2014 & Descriptive opinion piece & $\begin{array}{l}\text { - Posits generalism as the domain } \\
\text { of all general practitioners, with } \\
\text { the changing role of rural based } \\
\text { generalists. } \\
\text { - Outlines training programme for } \\
\text { rural generalist of the RACGP. }\end{array}$ \\
\hline Kitchener [50] & Australia & 2013 & Descriptive opinion piece & $\begin{array}{l}\text { - Overview of the challenges } \\
\text { and issues arising from the } \\
\text { Queensland RGP and argues } \\
\text { for regional training providers } \\
\text { to address some of the training } \\
\text { issues regarding private and } \\
\text { public placements. }\end{array}$ \\
\hline Larkins and Evans [73] & Australia & 2014 & Descriptive opinion piece & $\begin{array}{l}\text { - Advocates policy support for } \\
\text { Rural Generalists. }\end{array}$ \\
\hline
\end{tabular}


Table 6 Summary of included papers by region (Continued)

\begin{tabular}{|c|c|c|c|c|}
\hline Author (citation number) & Location & Year & Study design/methods/sample & Findings/critique \\
\hline Lawrance [39] & Australia & 2007 & Literature review & $\begin{array}{l}\text { - Questions the use of term 'rural } \\
\text { generalism' in Australia based } \\
\text { on the US model of community } \\
\text { based training programmes. } \\
\text { - The main application for the } \\
\text { term in Australia, then, is to } \\
\text { describe a state government } \\
\text { (Qld) hospital role. The author } \\
\text { claims this is a government } \\
\text { definition for a government } \\
\text { purpose. }\end{array}$ \\
\hline Lee [38] & Australia & 2015 & Descriptive opinion piece & $\begin{array}{l}\text { - Provides an historical account } \\
\text { of the evolution of generalism } \\
\text { and an overview of the different } \\
\text { definitions. } \\
\text { - Supports the development of } \\
\text { a definition that embraces the } \\
\text { diversity of approaches and } \\
\text { settings in generalism and } \\
\text { argues that a political approach } \\
\text { is needed to revive the generalist } \\
\text { profession. }\end{array}$ \\
\hline Manahan et al. [23] & Australia & 2011 & $\begin{array}{l}\text { Programme description } \\
\text { (conference paper) }\end{array}$ & $\begin{array}{l}\text { - Background discussion on QRGP } \\
\text { and the outcomes of the research } \\
\text { into the advanced skills. } \\
\text { - Also raises the concept of the rural } \\
\text { generalist as applicable in other } \\
\text { jurisdictions, and perhaps in other } \\
\text { disciplines. }\end{array}$ \\
\hline Mason [88] & Australia & 2013 & $\begin{array}{l}\text { Government (commissioned) } \\
\text { report }\end{array}$ & $\begin{array}{l}\text { - Proposes a new rural training } \\
\text { pathway to support the training } \\
\text { of both rural generalist specialists } \\
\text { and rural generalist GPs. The } \\
\text { proposed model focusses on a } \\
\text { regionally coordinated programme } \\
\text { from undergraduate through to } \\
\text { fellowship. }\end{array}$ \\
\hline McKenzie et al. [110] & Australia & 2013 & Quantitative study_survey & $\begin{array}{l}\text { - Overall this study of outcomes } \\
\text { from advanced rural skills training } \\
\text { in Qld has shown that the majority } \\
\text { of GPs and Rural Generalists are } \\
\text { using their advanced procedural } \\
\text { and non-procedural skills but also } \\
\text { that there is room for improvement. } \\
\text { - Unlikely that this study is not } \\
\text { representative of results of other } \\
\text { states and territories. }\end{array}$ \\
\hline Murdoch and Denz-Penhey [74] & Australia & 2007 & Descriptive opinion piece & $\begin{array}{l}\text { - Argues that main rural medical } \\
\text { workforce has to be made up } \\
\text { of contextually trained rural } \\
\text { generalists. } \\
\text { - Supports an academic discipline } \\
\text { of rural and remote medicine } \\
\text { supported through medical school, } \\
\text { postgraduate councils and colleges } \\
\text { - Needs to be an increased training } \\
\text { focus on rural medical generalists } \\
\text { from rural student recruitment to } \\
\text { established rural career, via } \\
\text { undergraduate education, rural } \\
\text { pre-vocational postings, and } \\
\text { vocational and continuing } \\
\text { education. }\end{array}$ \\
\hline Murray and Wronski [87] & Australia & 2006 & Descriptive opinion piece & $\begin{array}{l}\text { Describes the need to increase } \\
\text { the medical generalist training to }\end{array}$ \\
\hline
\end{tabular}


Table 6 Summary of included papers by region (Continued)

\begin{tabular}{|c|c|c|c|c|}
\hline Author (citation number) & Location & Year & Study design/methods/sample & Findings/critique \\
\hline & & & & $\begin{array}{l}\text { develop a workforce that can } \\
\text { provide primary and secondary } \\
\text { care. }\end{array}$ \\
\hline Nixon et al. [58] & New Zealand & 2007 & Descriptive opinion piece & $\begin{array}{l}\text { - Describes moves in NZ to } \\
\text { establish a professional body } \\
\text { for rural hospital generalist } \\
\text { doctors and to recognise the } \\
\text { role as a scope of practice. }\end{array}$ \\
\hline $\begin{array}{l}\text { Northern Territory Government } \\
\text { Department of Health [27] }\end{array}$ & Australia & 2016 & Programme description & $\begin{array}{l}\text { - Definition of RG_similar to Qld. } \\
\text { - RG pathway offers guaranteed } \\
\text { training places, priority rotations } \\
\text { and structured mentoring, } \\
\text { supervision and support. } \\
\text { - ASTs are anaesthetics, obstetrics } \\
\text { and emergency medicine. } \\
\text { - ASTs under development are } \\
\text { Internal Medicine, Surgery and } \\
\text { Paediatrics. }\end{array}$ \\
\hline Nova Public Policy Pty Ltd. [8] & Australia & 2010 & $\begin{array}{l}\text { Government (commissioned) } \\
\text { Report }\end{array}$ & $\begin{array}{l}\text { - Examines whether the QRGP could } \\
\text { potentially be expanded nationally. } \\
\text { - The conclusion reached is that } \\
\text { there are some core principles to } \\
\text { the programme that could be } \\
\text { adopted in all jurisdictions. } \\
\text { - Includes a broad international } \\
\text { literature scan. }\end{array}$ \\
\hline Pashen et al. [42] & Australia & 2007 & Systematic review & $\begin{array}{l}\text { - Comprehensive research study } \\
\text { into a range of key components } \\
\text { of rural generalism, including: } \\
\text { - Definitions } \\
\text { - Scopes of practice } \\
\text { - Workforce supply } \\
\text { - Education and training } \\
\text { - Procedural skills } \\
\text { - Funding } \\
\text { - Safety and quality } \\
\text { - Service provision models } \\
\text { - Legislation } \\
\text { - Clinical privileging }\end{array}$ \\
\hline Pereria [57] & Australia & 2010 & Descriptive opinion piece & $\begin{array}{l}\text { - Dr identifying as a Rural } \\
\text { Generalist and the advanced } \\
\text { skills practised (general } \\
\text { anaesthesia, obstetrics, including } \\
\text { forcep and caesarean sections, } \\
\text { and in-patient and emergency care). }\end{array}$ \\
\hline Queensland Health [24] & Australia & 2016 & Programme description & $\begin{array}{l}\text { - QRGP overview. Aims to } \\
\text { provide medical graduates } \\
\text { with a supported training } \\
\text { pathway to a career in rural } \\
\text { medicine and rural and remote } \\
\text { communities with a medical } \\
\text { workforce. } \\
\text { - Defines the RG and lists what } \\
\text { the QRGP offers in terms } \\
\text { of supported training and } \\
\text { quarantined places. } \\
\text { - Links to further details including } \\
\text { background and the application } \\
\text { process. }\end{array}$ \\
\hline $\begin{array}{l}\text { Queensland Health } \\
\text { (Ernst and Young) [49] }\end{array}$ & Australia & 2013 & Government report & $\begin{array}{l}\text { - Evaluation of the QRGP. } \\
\text { - The study presents the strengths } \\
\text { and criticisms of the QRGP to } \\
\text { date and a cost analysis base on } \\
\text { a return on investment model. }\end{array}$ \\
\hline
\end{tabular}


Table 6 Summary of included papers by region (Continued)

\begin{tabular}{|c|c|c|c|c|}
\hline Author (citation number) & Location & Year & Study design/methods/sample & Findings/critique \\
\hline RDAA [89] & Australia & 2012 & Position paper & $\begin{array}{l}\text { - Proposes a National Advanced } \\
\text { Rural Training Program with } \\
\text { a strong focus on principles } \\
\text { underpinning a national } \\
\text { approach to supporting rural } \\
\text { generalist training. }\end{array}$ \\
\hline Rural Health West [52] & Australia & 2015 & $\begin{array}{l}\text { Quantitative and Qualitative } \\
\text { study—surveys and interviews }\end{array}$ & $\begin{array}{l}\text { - The capacity to practise } \\
\text { procedural skills was the } \\
\text { 4th highest influence on } \\
\text { going rural. However, } \\
\text { concerns about workload } \\
\text { was also a negative factor } \\
\text { about going rural. } \\
\text { - Doctors recognised recent } \\
\text { efforts to develop a rural } \\
\text { generalist pathway but there } \\
\text { was a general lack of awareness } \\
\text { as to when and how the WA } \\
\text { rural generalist practice pathway } \\
\text { will be implemented. }\end{array}$ \\
\hline $\begin{array}{l}\text { Senate Community Affairs } \\
\text { Committee Secretariat [85] }\end{array}$ & Australia & 2012 & Government report & $\begin{array}{l}\text { - Examines factors affecting } \\
\text { the supply and distribution } \\
\text { of health services and medical } \\
\text { professionals in rural areas. } \\
\text { The Senate Committee stated } \\
\text { their strong support for the } \\
\text { Queensland RGP and } \\
\text { recommends expansion } \\
\text { of RG pathways. }\end{array}$ \\
\hline Sen Gupta et al. [111] & Australia & 2013 & Descriptive opinion piece & $\begin{array}{l}\text { - Responds to the Kitchener } \\
\text { article on the QRGP } \\
\text { - Acknowledges unintended } \\
\text { consequences for the } \\
\text { 'equilibrium' in the private } \\
\text { sector but argues that } 34 \\
\text { of } 111 \text { trainees in year } 3 \text { or } \\
\text { beyond are concurrently or } \\
\text { wholly in private practice, } \\
\text { the same proportion as } \\
\text { the } 30 \% \text { reported in } 2011 \text {. }\end{array}$ \\
\hline Sen Gupta et al. [48] & Australia & 2013 & Programme Description & $\begin{array}{l}\text { - Definition provided of rural } \\
\text { generalist as an extended } \\
\text { medical generalist. } \\
\text { - Background provided to } \\
\text { Queensland programme. } \\
\text { - Queensland pathway } \\
\text { characterised by both } \\
\text { training and employment } \\
\text { reform. }\end{array}$ \\
\hline Sondergeld and Nicholas [112] & Australia & 1998 & $\begin{array}{l}\text { Quantitative and qualitative } \\
\text { study—survey and interviews }\end{array}$ & $\begin{array}{l}\text { - Indicates a clear relationship } \\
\text { between rural GPs ceasing } \\
\text { procedural work and the level } \\
\text { of their indemnity premium } \\
\text { (a barrier of the time of writing). }\end{array}$ \\
\hline Stratigos and Nichols [4] & Australia & 2002 & Position paper & $\begin{array}{l}\text { - Reforms priorities for the rural } \\
\text { generalist workforce in: } \\
\text { 1. Training } \\
\text { 2. Indemnity } \\
\text { 3. Local facilities and equipment } \\
\text { 4. Social and financial issues } \\
\text { 5. Retention } \\
\text { 6. Continuing Medical Education } \\
\text { and Upskilling }\end{array}$ \\
\hline
\end{tabular}


Table 6 Summary of included papers by region (Continued)

\begin{tabular}{|c|c|c|c|c|}
\hline Author (citation number) & Location & Year & Study design/methods/sample & Findings/critique \\
\hline & & & & $\begin{array}{l}\text { - There is no evidence that } \\
\text { outreach programmes provide } \\
\text { a viable alternative to local } \\
\text { procedural practice and } \\
\text { therefore can only act as a } \\
\text { supplementary workforce. } \\
\text { Continuity of care is a key } \\
\text { reason for this. }\end{array}$ \\
\hline Tolhurst et al. [70] & Australia & 2006 & Qualitative study_interviews & $\begin{array}{l}\text { - Explores factors influencing } \\
\text { urban background medical } \\
\text { students' interest in rural } \\
\text { practice. } \\
\text { - One of the 'work preference' } \\
\text { results indicated the ability } \\
\text { to undertake procedural } \\
\text { work in hospitals as well as } \\
\text { provide primary GP care } \\
\text { as an influencing factor. }\end{array}$ \\
\hline Wainer [113] & Australia & 2004 & Quantitative study—survey & $\begin{array}{l}\text { - Women make up less than } \\
\text { a quarter of the rural general } \\
\text { practice workforce and an } \\
\text { even smaller percentage of } \\
\text { the specialist rural medical } \\
\text { workforce. Their experiences } \\
\text { are not well articulated in } \\
\text { research and policy on rural } \\
\text { medical practice. } \\
\text { - The incoming cohort of } \\
\text { rural general practitioners } \\
\text { has a majority of women. } \\
\text { - Recommendations include } \\
\text { linking female medical } \\
\text { students with female rural } \\
\text { doctors, matching trainees } \\
\text { with female mentors, } \\
\text { adequate skill development } \\
\text { in areas important to rural } \\
\text { practice, and ensuring a } \\
\text { career path in rural practice. }\end{array}$ \\
\hline Worley et al. [41] & Australia & 2000 & Qualitative study_interviews & $\begin{array}{l}\text { - Overview of the Parallel } \\
\text { Rural Community Curriculum } \\
\text { (PRCC). } \\
\text { - PRCC affirmed the potential } \\
\text { role of true generalist physicians } \\
\text { in undergraduate medical } \\
\text { education. } \\
\text { - The students developed a high } \\
\text { level of competence in procedural } \\
\text { skills and an increased confidence } \\
\text { with patients. }\end{array}$ \\
\hline
\end{tabular}

North America

Angle et al. [79]

Canada

Qualitative study—secondary analysis of qualitative data
- Explored barriers experienced by physicians in providing obstetrical anaesthesia care in Ontario community hospitals that experience low volume deliveries per year.

- Difficulties were greatest for FP/GP anaesthetists in rural communities due to lack of locums, the need for relevant $\mathrm{CME}$, and worsening physician shortages threatening the provision of services in some rural hospitals. 
Table 6 Summary of included papers by region (Continued)

\begin{tabular}{|c|c|c|c|c|}
\hline Author (citation number) & Location & Year & Study design/methods/sample & Findings/critique \\
\hline & & & & $\begin{array}{l}\text { - Need for increased numbers } \\
\text { of FP/GP anaesthetists and } \\
\text { the development of formal } \\
\text { funded networks for knowledge } \\
\text { transfer between academic and } \\
\text { community hospitals as means } \\
\text { of providing supports. }\end{array}$ \\
\hline Aubrey-Bassler et al. [68] & Canada & 2007 & Quantitative data analysis & $\begin{array}{l}\text { - Authors concluded that these } \\
\text { GPs performed caesarean } \\
\text { sections with an acceptable } \\
\text { degree of safety compared } \\
\text { with specialists. }\end{array}$ \\
\hline Avery et al. [114] & Canada & 2014 & Descriptive opinion piece & $\begin{array}{l}\text { - The authors express their } \\
\text { concern about the Privileging } \\
\text { Standards Project and the } \\
\text { methodology involved in the } \\
\text { project to establish a minimum } \\
\text { number of procedures to maintain } \\
\text { currency. } \\
\text { - The unintended consequence of } \\
\text { this project could be the departure } \\
\text { of rural generalists with skills from } \\
\text { British Columbia with advanced } \\
\text { skills in surgery, anaesthesia, } \\
\text { emergency, and maternity care. }\end{array}$ \\
\hline Baker et al. [115] & USA & 2010 & Quantitative study—survey & $\begin{array}{l}\text { - Results identified a broad range } \\
\text { of advanced skills practised by } \\
\text { rural Family Practitioners in Idaho } \\
\text { including obstetrics, Colonoscopy, } \\
\text { Emergency room coverage and } \\
\text { mental health services. }\end{array}$ \\
\hline Bronstein [78] & USA & 1992 & $\begin{array}{l}\text { Quantitative study-survey } \\
\text { and data analysis }\end{array}$ & $\begin{array}{l}\text { - This analysis distinguishes } \\
\text { between counties with larger } \\
\text { populations and counties with } \\
\text { smaller populations. } \\
\text { - Rural generalist physicians } \\
\text { were more likely than rural } \\
\text { specialists to have at least two } \\
\text { of the components required } \\
\text { to maintain obstetrics services. } \\
\text { However more of these } \\
\text { physicians than any other } \\
\text { group left obstetrics over this } \\
\text { period. } \\
\text { - Specialists entered markets } \\
\text { where generalists used to } \\
\text { practise, driving the generalists } \\
\text { to more rural areas or out of } \\
\text { obstetrics practice altogether. }\end{array}$ \\
\hline Crutcher et al. [44] & Canada & 2005 & Quantitative study—survey & $\begin{array}{l}\text { - This study examines where } \\
\text { Canadian family medicine } \\
\text { graduates learned to do the } \\
\text { procedures they perform. The } \\
\text { findings reinforce the important } \\
\text { role that medical schools and } \\
\text { residency training programmes } \\
\text { play in teaching procedural skills } \\
\text { to family medicine residents. } \\
\text { - They also show that rural family } \\
\text { physicians perform a greater } \\
\text { volume of procedures than } \\
\text { those in urban practices. }\end{array}$ \\
\hline De Klerk [18] & Canada & 2013 & Descriptive opinion piece & $\begin{array}{l}\text { - Generalism has given way to } \\
\text { medical specialisation in Canada } \\
\text { (and many other countries) over }\end{array}$ \\
\hline
\end{tabular}


Table 6 Summary of included papers by region (Continued)

Author (citation number) Location $\quad$ Year
Study design/methods/sample Findings/critique

De Klerk [31]

Canada

2014

Descriptive opinion piece

Evans et al. [116]

USA the past 60 years and this does

not serve the dispersed

Canadian population well.

- The Society of Rural Physicians

is advocating for a countrywide rural curriculum in medical schools to produce a welltrained doctor with the necessary knowledge and skills to pursue a career in rural medicine.

- Describes the recommendations of the Cairns Consensus Statement from the First World Summit on Rural Generalist Medicine.

- Rural generalist medicine embraces the Triple $C$ principles of The College of Family Physicians of Canada: competency-based curriculum of comprehensive care, focused on continuity of education and patient care, and centred in family medicine.

- Review of studies of rural colonoscopy to determine speciality types providing rural colonoscopy and the quality of these procedures.

- Concludes that rural generalist physicians can safely and effectively perform colonoscopies.

- This review was performed to discover what has been learned from various initiatives taken by pre-doctoral and graduate medical education programmes to encourage choice and preparation for rural medical practice.

- Family practice the predominant speciality upon which small rural health systems need to be based.

- Rural physicians need to have procedural skills in emergency medicine, surgery, obstetrics and perhaps anaesthesia; be skilled in community medicine, have computer and business skills; and also be attuned to team and group practice.

- More family practice graduates in rural areas performing almost all types of obstetrical care

- Relatively more female than male family physicians, regardless of practice location, provide obstetrical care, including obstetrical procedures.

- Recommends that curriculum for the training of Family Practitioners that intend to go rural should include more procedural and obstetric care.

- Canadian Family Physician College (CFPC) decision in 2008 to approve Family Physician with Special Interest or Focused Practice 
Table 6 Summary of included papers by region (Continued)

\begin{tabular}{|c|c|c|c|c|}
\hline Author (citation number) & Location & Year & Study design/methods/sample & Findings/critique \\
\hline & & & & $\begin{array}{l}\text { (SIFP) to accredit enhanced skills } \\
\text { that meet the Triple C curriculum } \\
\text { standards. } \\
\text { - The need for SIFP was particularly } \\
\text { relevant to rural family physicians } \\
\text { with a strong need to meet needs } \\
\text { of their communities. }\end{array}$ \\
\hline Hart [17] & USA & 2000 & $\begin{array}{l}\text { Quantitative analysis and } \\
\text { literature review (conference } \\
\text { paper) }\end{array}$ & $\begin{array}{l}\text { - Focus on the supply, distribution } \\
\text { and training of generalists into } \\
\text { rural areas, with mention of the } \\
\text { importance of advanced skills } \\
\text { training in developing rural } \\
\text { generalists equipped to } \\
\text { undertake the range of care } \\
\text { required. } \\
\text { - Also looks at current } \\
\text { programmes aimed at } \\
\text { producing a rural medical } \\
\text { workforce and concludes } \\
\text { that the current attempts } \\
\text { to ensure an adequate supply } \\
\text { of providers in underserved } \\
\text { areas is proving problematic. }\end{array}$ \\
\hline Hutten-Czapski [69] & Canada & 1998 & Descriptive opinion piece & $\begin{array}{l}\text { - Describes some of political } \\
\text { activity around rural obstetrics } \\
\text { in Canada as provided by } \\
\text { family physicians, despite } \\
\text { increasing evidence of safe } \\
\text { outcomes. }\end{array}$ \\
\hline Hutten-Czapski [117] & Canada & 2015 & Descriptive opinion piece & $\begin{array}{l}\text { - Argues that using statistics } \\
\text { to support any argument that } \\
\text { low volume obstetric care } \\
\text { in rural areas provided by } \\
\text { generalists equates to low } \\
\text { quality is not supported by } \\
\text { research. } \\
\text { - Low-volume obstetrics has } \\
\text { been found to be at least } \\
\text { as safe as obstetrics practiced } \\
\text { in big centres. }\end{array}$ \\
\hline Iglesias and Hutten-Czapski [118] & Canada & 1999 & $\begin{array}{l}\text { Descriptive opinion piece, } \\
\text { including a literature review }\end{array}$ & $\begin{array}{l}\text { - Advocates for an integrated } \\
\text { advanced maternity care } \\
\text { training programme for } \\
\text { rural family physicians as } \\
\text { a way of continuing to } \\
\text { provide rural services in } \\
\text { Canada in a time of a rapid } \\
\text { decline in the availability of } \\
\text { rural maternity services. }\end{array}$ \\
\hline Imrie et al. [6] & Canada & 2011 & Literature review & $\begin{array}{l}\text { - In recent years some family } \\
\text { physicians have integrated } \\
\text { additional competencies into } \\
\text { the development of focused } \\
\text { practices in family medicine, } \\
\text { including areas such as } \\
\text { emergency medicine, palliative } \\
\text { care, elder care and rural care. } \\
\text { - It is also stated that generalism } \\
\text { is not just a rural and remote } \\
\text { practice but that it is important } \\
\text { also in urban settings. }\end{array}$ \\
\hline Inglis [53] & Canada & 1995 & Descriptive opinion piece & $\begin{array}{l}\text { - Describes the work being } \\
\text { undertaken by a collaboration } \\
\text { between Colleges to develop } \\
\text { an agreed set of guidelines for }\end{array}$ \\
\hline
\end{tabular}


Table 6 Summary of included papers by region (Continued)

\begin{tabular}{|c|c|c|c|c|}
\hline Author (citation number) & Location & Year & Study design/methods/sample & Findings/critique \\
\hline & & & & $\begin{array}{l}\text { the provision of surgical services } \\
\text { delivered by GPs in rural areas. } \\
\text { The guidelines were intended } \\
\text { to enable the development of } \\
\text { a training curriculum for rural } \\
\text { surgery for GPs. }\end{array}$ \\
\hline Jong [90] & Canada & 2007 & Descriptive opinion piece & $\begin{array}{l}\text { - Small communities in } \\
\text { Canada cannot sustain } \\
\text { narrowly focused specialists. } \\
\text { Instead more generalists } \\
\text { and more rural doctors with } \\
\text { broad and enhanced skills } \\
\text { are required. Commitment } \\
\text { was made in } 2007 \text { by the } \\
\text { Canadian Medical Association } \\
\text { to address the scarcity of } \\
\text { generalist FP/GPs and generalist } \\
\text { specialists and to improve access } \\
\text { to enhanced skill sets training. }\end{array}$ \\
\hline Kornelsen et al. [66] & Canada & 2013 & Qualitative study_-interviews & $\begin{array}{l}\text { - One of the solutions to doctor } \\
\text { shortages in rural Canada is to } \\
\text { promote the use of general } \\
\text { practitioner surgeons (GPS). } \\
\text { This is under threat however } \\
\text { due to the due to the lack of } \\
\text { interprofessional support } \\
\text { garnered in education and } \\
\text { practice. } \\
\text { - Interprofessional conflict with } \\
\text { professional boundary issues } \\
\text { between surgeons and GPSs } \\
\text { has prevented the increased } \\
\text { update of the GPS role in } \\
\text { rural Canada. } \\
\text { - For populations of 5000-15000, } \\
\text { surgical services are provided } \\
\text { locally by one or more GPS. For } \\
\text { populations of } 15000-25000 \text {, } \\
\text { there is usually a specialist } \\
\text { surgeon supported by one } \\
\text { or more GPS ('mixed' model). }\end{array}$ \\
\hline Lew et al. [80] & USA & 2009 & Quantitative study—survey & $\begin{array}{l}\text { - In rural areas EDs are } \\
\text { often staffed by primary } \\
\text { care physicians, rather } \\
\text { than emergency medicine } \\
\text { trained specialists. } \\
\text { - More than one third of } \\
\text { the respondent physicians } \\
\text { currently covering the ED } \\
\text { reported that they derive } \\
\text { greater than } 40 \% \text { of their } \\
\text { income from working in it. } \\
\text { - Respondents covering ED } \\
\text { expressed low confidence } \\
\text { in dealing with paediatric } \\
\text { emergencies and highlighted } \\
\text { a need for more training in } \\
\text { this area. }\end{array}$ \\
\hline Lockyer and Norton [54] & Canada & 2005 & Descriptive opinion piece & $\begin{array}{l}\text { - The authors document the } \\
\text { process involved in creating } \\
\text { a collaborative, intersectoral } \\
\text { approach to developing the } \\
\text { Standards for Accreditation } \\
\text { of Residency Training } \\
\text { Programs arising from the } \\
\text { need to resolve the FPA }\end{array}$ \\
\hline
\end{tabular}


Table 6 Summary of included papers by region (Continued)

\begin{tabular}{|c|c|c|c|c|}
\hline Author (citation number) & Location & Year & Study design/methods/sample & Findings/critique \\
\hline & & & & $\begin{array}{l}\text { immediate needs but also } \\
\text { has application to the } \\
\text { support and development } \\
\text { of FP Surgeons and FP } \\
\text { Obstetricians across rural } \\
\text { Canada. }\end{array}$ \\
\hline MacLellan [30] & Canada & 2006 & Descriptive opinion piece & $\begin{array}{l}\text { - Provides a view of the rural } \\
\text { generalist as constantly } \\
\text { moving along the spectrum } \\
\text { between specialisation and } \\
\text { integration. } \\
\text { - Argues that rural Canada } \\
\text { needs the generalist with } \\
\text { defined competencies, } \\
\text { constantly fluctuating } \\
\text { between the primary, } \\
\text { secondary and tertiary } \\
\text { levels of care. }\end{array}$ \\
\hline Maudlin and Newkirk [46] & USA & 2010 & Descriptive opinion piece & $\begin{array}{l}\text { - Overview of Family Medicine } \\
\text { Spokane (FMS, established as } \\
\text { a collaborative effort by the } \\
\text { University of Washington } \\
\text { School of Medicine (UWSOM), } \\
\text { four Eastern Washington } \\
\text { community hospitals in } \\
\text { Spokane, and the Spokane } \\
\text { County Medical Society. } \\
\text { - Of the } 235 \text { graduates of } \\
\text { the FMS, } 49 \% \text { practice } \\
\text { rurally (defined as a } \\
\text { community of less than } \\
25000 \text { population located } \\
\text { more than } 25 \text { miles from a } \\
\text { town larger than } 25 \text { 000). } \\
\text { - To increase the number of } \\
\text { graduates going rural, the } \\
\text { FMS Rural Training Track } \\
\text { (FMSRT) in Colville, was } \\
\text { approved as an 'experimental } \\
\text { pathway' of FMS. } \\
\text { - Of the } 35 \text { graduates of the } \\
\text { FMSRTT, } 77 \% \text { practice in } \\
\text { rural communities. }\end{array}$ \\
\hline Meyer et al. [119] & USA & 2000 & Quantitative data analysis & $\begin{array}{l}\text { - Generalists were more likely } \\
\text { to have performed a simple } \\
\text { diagnostic procedure, perform } \\
\text { the procedure for diagnostic } \\
\text { and screening purposes and } \\
\text { perform them in rural areas. } \\
\text { - Generalists often perform } \\
\text { less complex gastrointestinal } \\
\text { endoscopies. }\end{array}$ \\
\hline Miller et al. [93] & Canada & 2012 & $\begin{array}{l}\text { Position paper and a } \\
\text { literature review }\end{array}$ & $\begin{array}{l}\text { - Provides an overview of } \\
\text { current information on } \\
\text { issues in maternity care } \\
\text { relevant to rural populations. } \\
\text { - Importance of collaborative } \\
\text { practice models in rural and } \\
\text { remote maternity care, including } \\
\text { GP surgeons (with obstetrics) } \\
\text { and GP anaesthetists, with } \\
\text { support from enhanced roles } \\
\text { for nurses and nurse practitioners. } \\
\text { - Recommendations include } \\
\text { expanding advanced skills } \\
\text { training, including in caesarean }\end{array}$ \\
\hline
\end{tabular}


Table 6 Summary of included papers by region (Continued)

\begin{tabular}{|c|c|c|c|c|}
\hline Author (citation number) & Location & Year & Study design/methods/sample & Findings/critique \\
\hline & & & & $\begin{array}{l}\text { section and obstetrical anaesthesia } \\
\text { services for family physicians. }\end{array}$ \\
\hline Oberai et al. [94] & Canada & 2014 & Descriptive opinion piece & $\begin{array}{l}\text { - In rural Canada, family } \\
\text { physicians are the main } \\
\text { providers of maternity care. } \\
\text { - However, fewer Canadian } \\
\text { generalists are skilled in } \\
\text { advanced maternity care. } \\
\text { There has been a high rate } \\
\text { of attrition among physicians } \\
\text { who provide maternity care } \\
\text { in rural areas. } \\
\text { - If rural maternity care is to } \\
\text { continue in Canada, rural } \\
\text { practitioners will need training } \\
\text { in advanced maternity care. }\end{array}$ \\
\hline Ramsey et al. [45] & USA & 2001 & Descriptive opinion piece & $\begin{array}{l}\text { - Evolution of the University } \\
\text { of Washington School of } \\
\text { Medicine (UWSOM) to } \\
\text { increase generalist physicians } \\
\text { in the region with an } \\
\text { emphasis on rural practice. } \\
\text { - Known as the WAMl } \\
\text { programme after the first } \\
4 \text { participating states } \\
\text { (Washington, Alaska, } \\
\text { Montana and Idaho) and } \\
\text { also now includes Wyoming. } \\
\text { The WAMl programme is a } \\
\text { rural training pipeline from } \\
\text { undergraduate to residency } \\
\text { with an emphasis on community } \\
\text { practice training, including the } \\
\text { Family Medicine Spokane (FMS) } \\
\text { residency programme. }\end{array}$ \\
\hline Rivet et al. [71] & Canada & 2007 & $\begin{array}{l}\text { Quantitative study-secondary } \\
\text { analysis of a population survey }\end{array}$ & $\begin{array}{l}\text { - The range of procedures } \\
\text { done by family physicians } \\
\text { was significantly linked to } \\
\text { job satisfaction. The larger } \\
\text { the range of procedures, } \\
\text { the more satisfied the } \\
\text { physician. Rural physicians } \\
\text { were also more satisfied } \\
\text { than urban. }\end{array}$ \\
\hline Sisler et al. [120] & Canada & 2013 & Quantitative study—survey & $\begin{array}{l}\text { - Overview of GP Oncologists. } \\
\text { - Whist this is not a strictly rural } \\
\text { vocation, the role of FPs with } \\
\text { focused practices is particularly } \\
\text { critical in rural Canada. }\end{array}$ \\
\hline Soles [59] & Canada & 2015 & Descriptive opinion piece & $\begin{array}{l}\text { - Highlights the move away } \\
\text { from generalism and its } \\
\text { impact on rural communities } \\
\text { in Canada. } \\
\text { - Supports the principles of } \\
\text { rural generalism in the Cairns } \\
\text { Consensus Statement in } \\
\text { addressing rural community } \\
\text { need. }\end{array}$ \\
\hline Thompson and Iglesias [55] & Canada & 1998 & Descriptive opinion piece & $\begin{array}{l}\text { - Describes a proposed model } \\
\text { of shared skill sets for the } \\
\text { teaching and evaluation of } \\
\text { rural generalist physicians with } \\
\text { advanced skills. } \\
\text { - Also raises the possibility of the } \\
\text { establishment of a college for rural }\end{array}$ \\
\hline
\end{tabular}


Table 6 Summary of included papers by region (Continued)

\begin{tabular}{|c|c|c|c|c|}
\hline Author (citation number) & Location & Year & Study design/methods/sample & Findings/critique \\
\hline & & & & $\begin{array}{l}\text { medicine in Canada as a way of } \\
\text { preparing rural generalists } \\
\text { with the advanced skills } \\
\text { needed in rural areas. } \\
\text { - Describes the need for FPs } \\
\text { to identify skills set needed } \\
\text { for RG advanced scopes of } \\
\text { practice. Areas where some } \\
\text { work has been done includes } \\
\text { O\&G and Anaesthetics. More } \\
\text { needs to be done on areas of } \\
\text { general \surgery and endoscopy. }\end{array}$ \\
\hline Urbina et al. [72] & USA & 1994 & Descriptive opinion piece & $\begin{array}{l}\text { - The authors discuss both the } \\
\text { problem and various existing } \\
\text { innovative strategies to prepare } \\
\text { a generalist medical workforce } \\
\text { (in family practice, internal } \\
\text { medicine and paediatrics) with } \\
\text { a strong focus on rural. } \\
\text { - This article also describes the } \\
\text { subspeciality domination of } \\
\text { hospital based graduate medical } \\
\text { education and the impact of } \\
\text { that on generalist training. }\end{array}$ \\
\hline Wetmore et al. [121] & Canada & 2005 & Quantitative study—survey & $\begin{array}{l}\text { - The objective of this study } \\
\text { was to create a list of core and } \\
\text { enhanced procedures suitable } \\
\text { for family medicine training. } \\
\text { - Sixty-five core procedures and } \\
15 \text { enhanced procedures were } \\
\text { identified. }\end{array}$ \\
\hline Williams [32] & USA & 1998 & Quantitative data analysis & $\begin{array}{l}\text { - Rural generalist family physician } \\
\text { practices require different skills, } \\
\text { are faster paced and demand } \\
\text { more time and must deal } \\
\text { with higher burdens of illness } \\
\text { compared with urban practices. } \\
\text { The higher level of hospital } \\
\text { intensive care and obstetrical } \\
\text { privileges and greater use of } \\
\text { procedures by rural family } \\
\text { physicians support these } \\
\text { observations. } \\
\text { - The rural family physician } \\
\text { workforce however has } \\
\text { continued to decline, whilst } \\
\text { the urban rates increased. }\end{array}$ \\
\hline Wootton [92] & Canada & 2007 & Descriptive opinion piece & $\begin{array}{l}\text { - Rural physicians should be able } \\
\text { to provide the required secondary } \\
\text { care and also primary care in rural } \\
\text { areas. At present, primary care is } \\
\text { treated in education and training } \\
\text { programmes as the main focus } \\
\text { and this makes the advanced skills } \\
\text { training an ad hoc add on. }\end{array}$ \\
\hline \multicolumn{5}{|l|}{ Africa } \\
\hline De Villiers [96] & South Africa & 2004 & Descriptive opinion piece & $\begin{array}{l}\text { - Circumstances in South Africa } \\
\text { call for a well-trained generalist } \\
\text { that also includes practical/procedural } \\
\text { clinical skills regarded by some as } \\
\text { the domain of other specialties. The } \\
\text { FP should be positioned as the key } \\
\text { professional in the District Health } \\
\text { System. }\end{array}$ \\
\hline
\end{tabular}


Table 6 Summary of included papers by region (Continued)

\begin{tabular}{|c|c|c|c|c|}
\hline Author (citation number) & Location & Year & Study design/methods/sample & Findings/critique \\
\hline Downing [97] & Kenya & 2008 & Descriptive opinion piece & $\begin{array}{l}\text { - Family medicine cannot just be } \\
\text { primary care providers and the } \\
\text { priority for physicians in Kenya is } \\
\text { on being good generalists-which } \\
\text { requires not only inpatient care } \\
\text { but practising emergency surgery. }\end{array}$ \\
\hline Ellis [63] & Tristan da Cunha & 2008 & Descriptive opinion piece & $\begin{array}{l}\text { - Examples of practice and skills } \\
\text { requirements provides insight } \\
\text { into the scopes of practice } \\
\text { required of a rural generalist in } \\
\text { remote areas (Tristan da Cunha). }\end{array}$ \\
\hline Hill [64] & South Africa & 1995 & Descriptive opinion piece & $\begin{array}{l}\text { - Describes the procedural activity } \\
\text { in the town of Kokstad-a town } \\
\text { of } 25000 \text { people. } \\
\text { - Argues that primary care is not } \\
\text { enough to attract new doctors } \\
\text { and in state based hospitals, they } \\
\text { need to have additional procedural } \\
\text { skills, which makes the role more } \\
\text { attractive. } \\
\text { - Hill proposes more structured } \\
\text { secondary care training programmes } \\
\text { for generalists in procedural skills as } \\
\text { in Australia and Canada. }\end{array}$ \\
\hline Howe et al. [95] & South Africa & 2013 & Descriptive opinion piece & $\begin{array}{l}\text { - The authors argue that expert } \\
\text { family physician generalists are } \\
\text { required to support primary health } \\
\text { care as well as to provide care at } \\
\text { the district hospital. } \\
\text { - District hospitals, especially in } \\
\text { rural areas, require family physicians } \\
\text { with an extended range of skills in } \\
\text { hospital care. } \\
\text { - The challenge therefore for family } \\
\text { medicine training programmes is } \\
\text { to maximise the number of future } \\
\text { family physicians and to re-orientate } \\
\text { and 'up skill' the existing doctors for } \\
\text { their new roles in a reengineered } \\
\text { primary care. }\end{array}$ \\
\hline Levack and Levack [5] & Tristan da Cunha & 2013 & Descriptive opinion piece & $\begin{array}{l}\text { - Focus on the health workforce } \\
\text { needs of a remote island, Tristan } \\
\text { da Cunha. }\end{array}$ \\
\hline Monjok et al. [13] & Nigeria & 2010 & Descriptive opinion piece & $\begin{array}{l}\text { - Proposes a short obstetric-training } \\
\text { programme for generalist medical } \\
\text { officers to increase the number of } \\
\text { skilled birth attendants in both rural } \\
\text { and peripheral health facilities in } \\
\text { Nigeria. }\end{array}$ \\
\hline Philpott et al. [12] & Ethiopia & 2014 & Descriptive opinion piece & $\begin{array}{l}\text { - Ethiopia's first training programme } \\
\text { in family medicine was launched } \\
\text { on February 4, 2013, at the Addis } \\
\text { Ababa University, College of Health } \\
\text { Sciences, School of Medicine. GPs } \\
\text { have been an important part of } \\
\text { the health system for decades } \\
\text { but until now there has been no } \\
\text { postgraduate training programme } \\
\text { for generalist physicians. The family } \\
\text { medicine programme aims to provide } \\
\text { such training, so that its graduates } \\
\text { will be highly skilled comprehensive- } \\
\text { care doctors for urban and rural areas } \\
\text { of Ethiopia who choose generalism } \\
\text { as a lifelong career choice. }\end{array}$ \\
\hline
\end{tabular}


Table 6 Summary of included papers by region (Continued)

\begin{tabular}{|c|c|c|c|c|}
\hline Author (citation number) & Location & Year & Study design/methods/sample & Findings/critique \\
\hline & & & & $\begin{array}{l}\text { - Family physicians working in } \\
\text { rural areas may act as consultants } \\
\text { to other health care workers, may } \\
\text { have greater community and public } \\
\text { health roles, and will be able to } \\
\text { provide emergency surgical and } \\
\text { obstetrical services. }\end{array}$ \\
\hline Reid et al. [62] & South Africa & 1999 & $\begin{array}{l}\text { Quantitative data analysis and } \\
\text { qualitative study - interviews } \\
\text { (focus groups) }\end{array}$ & $\begin{array}{l}\text { - Defines the role and scope } \\
\text { of the rural generalist in } \\
\text { South Africa as extremely } \\
\text { wide and is often called } \\
\text { upon to perform clinical } \\
\text { activities ranging from } \\
\text { primary care to emergency } \\
\text { surgical procedures, as well } \\
\text { as leadership roles. } \\
\text { - Training in South Africa needs } \\
\text { to capture the specific skills of } \\
\text { the generalist and when the } \\
\text { rural generalist needs to refer } \\
\text { on for specialist care. } \\
\text { - Indicates the need for well- } \\
\text { planned support strategies for } \\
\text { doctors in rural hospitals at a } \\
\text { distance from specialist support. }\end{array}$ \\
\hline Reid et al. [61] & Africa & 2011 & Qualitative study_interviews & $\begin{array}{l}\text { - In Sub-Saharan Africa family } \\
\text { physicians and generalist } \\
\text { medical officers are likely to } \\
\text { need more surgical, anaesthetic } \\
\text { and procedural skills to provide } \\
\text { services at the district hospital, } \\
\text { as well as skills in consulting, } \\
\text { mentoring and teaching to } \\
\text { support the front line primary } \\
\text { care workers. } \\
\text { - Curricula should ensure that } \\
\text { clinical training is sufficiently } \\
\text { comprehensive to ensure } \\
\text { competency across a broad } \\
\text { range of diagnoses and } \\
\text { procedures. }\end{array}$ \\
\hline Thigiti et al. [47] & Kenya & 2011 & $\begin{array}{l}\text { Programme description } \\
\text { (conference paper) }\end{array}$ & $\begin{array}{l}\text { - Overview of the Kenyan Moi } \\
\text { University Master of Family } \\
\text { Medicine Training Program, } \\
\text { which aimed to address the } \\
\text { lack of generalists in Kenya } \\
\text { and prepares family physicians } \\
\text { for their role as Superintendents } \\
\text { in peripheral hospitals or as } \\
\text { District Medical Officers. } \\
\text { - This programme is increasing } \\
\text { access to health care, especially } \\
\text { for rural and poor underserved } \\
\text { communities and is expanding } \\
\text { into Uganda and Rwanda. }\end{array}$ \\
\hline \multicolumn{5}{|l|}{ Europe } \\
\hline Boerma et al. [22] & Europe & 1998 & Quantitative study—survey & $\begin{array}{l}\text { - Procedural tasks were greater } \\
\text { for rural GPs and for those } \\
\text { practising at greater distance } \\
\text { from the nearest hospital. } \\
\text { However this was only } \\
\text { true of western European } \\
\text { countries and where the } \\
\text { GP was self-employed. }\end{array}$ \\
\hline
\end{tabular}


Table 6 Summary of included papers by region (Continued)

\begin{tabular}{|c|c|c|c|c|}
\hline Author (citation number) & Location & Year & Study design/methods/sample & Findings/critique \\
\hline & & & & $\begin{array}{l}\text { - The authors also identify } \\
\text { studies that further show } \\
\text { that in the United Kingdom } \\
\text { and Netherlands, rural GPs } \\
\text { undertake more procedures } \\
\text { than their urban counterparts. }\end{array}$ \\
\hline Iversen et al. [81] & United Kingdom & 2002 & Qualitative study_interviews & $\begin{array}{l}\text { - Pressures of rural GPs } \\
\text { having to deal with } \\
\text { anything and everything } \\
\text { (such as minor surgery, } \\
\text { accident and emergency } \\
\text { work and dispensing), due } \\
\text { to small practice teams and } \\
\text { considerable distance from } \\
\text { general hospital services }\end{array}$ \\
\hline Tucker et al. [82] & Scotland & 2005 & $\begin{array}{l}\text { Quantitative and qualitative } \\
\text { study_survey and interviews }\end{array}$ & $\begin{array}{l}\text { - Medical workforce issues } \\
\text { and falling birth rates are } \\
\text { driving centralisation of acute } \\
\text { obstetric and neonatal services } \\
\text { in the United Kingdom, further } \\
\text { limiting geographical access for } \\
\text { remote and rural populations. } \\
\text { Some general practitioners in } \\
\text { this study noted that, because } \\
\text { they no longer obtained much } \\
\text { obstetric experience, any } \\
\text { intrapartum care in community } \\
\text { settings was increasingly } \\
\text { undertaken by midwives. }\end{array}$ \\
\hline Wiegers [83] & Europe & 2003 & Descriptive opinion piece & $\begin{array}{l}\text { - In Europe the role of GPs or } \\
\text { Family physicians in obstetrics } \\
\text { has been in steady decline and } \\
\text { do not get involved in high-risk } \\
\text { obstetrical care at all. }\end{array}$ \\
\hline \multicolumn{5}{|l|}{ International } \\
\hline WHO [99] & International paper & 2010 & Position paper & $\begin{array}{l}\text { - There is evidence to show } \\
\text { that enhanced scopes of } \\
\text { practice leads to increased } \\
\text { job satisfaction. This resulted } \\
\text { in recommendation B1: } \\
\text { Introduce and regulate } \\
\text { enhanced scopes of practice } \\
\text { in rural and remote areas to } \\
\text { increase the potential for job } \\
\text { satisfaction, thereby assisting } \\
\text { recruitment and retention. } \\
\text { - Advanced procedural skills } \\
\text { training can enhance the } \\
\text { confidence of family } \\
\text { medicine residents in } \\
\text { rural areas and improve } \\
\text { their competence. }\end{array}$ \\
\hline
\end{tabular}

(ACRRM) [25]; and in Australian Commonwealth, state and territory government documents [1, 26-28]. More recently, ACRRM and the Royal Australian College of General Practitioners have supported a definition of a rural generalist that reflects the Cairns Consensus Statement: a medical practitioner trained to meet the health care needs of rural and remote communities by 'providing both comprehensive general practice and emergency care, and required components of other medical specialist care in hospital and community settings as part of a rural health team' [29].

The application of specialised skills by the RGM is a focus of definitions in North America [30-32]. However, there are also some variations in the literature from this region. In the United States of America (USA), 'generalism' is often used to jointly describe family physicians, general internists and general paediatricians [33-35]. In the USA and Australia, there has been some criticism of RGM as 
defined in this review [36, 37], which focuses mainly on the expansion of family medicine fellowship training into specialised skills [37] or efforts to distinguish and then define generalism by rurality $[38,39]$.

\section{Pathways and programmes}

This theme includes literature relevant to (i) medical school training designed to support and develop RGM and (ii) postgraduate (vocational) pathways and programmes.

\section{Undergraduate medical training}

Programmes supporting the development of RGM vary between countries, ranging from mature, governmentfunded models to new, and emerging programmes. In Australia, a medical student is not obliged to choose their speciality until they enter postgraduate (vocational) training, though there are medical school programmes supporting early-entry rural medical and generalist pathways [40-42]. A key example of this is university-based rural clinical schools [21], which emphasise rural recruitment, training in rural areas and rural graduate practice. These programmes have been shown to provide a strong foundation for attracting medical students to rural practice [43].

A Canadian study highlights the role of medical schools and residency training programmes in teaching procedural skills to rural family medicine residents [44]. The University of Washington School of Medicine (USA) established the 'WAMI' programme to increase generalist graduates in the region with an emphasis on rural practice [45]. This rural training 'pipeline' emphasises community practice training, including the Family Medicine Spokane residency programme, with specialised skills rotations $[45,46]$.

The Moi University Master of Family Medicine Training Program (Kenya) aims to address a shortage of generalists and prepares family physicians for roles as superintendents in regional hospitals, or as district medical officers [47]. This provides access to comprehensive health care services, especially for rural and underserved communities.

\section{Postgraduate pathways and programmes}

Six Australian state and territory governments have funded structured and supported prevocational and vocational RGM training pathways [1]. The QRGP offers postgraduate medical trainees:

- Advice and support services

- Access to a range of vocational and quarantined training opportunities

- Procedural and non-procedural training workshops [24]

The QRGP is supported by an industrial agreement that has enabled salaried senior medical officers with RGM credentials to access a higher salary range equivalent to staff specialists [48]. The QRGP is both a training and employment pathway that is founded on four 'pillars': recognition of RGM, practice value, a pathway to vocational practice and responsiveness to workforce redesign [49]. Evaluation of the programme found numerous community, workforce and economic benefits, with a cost analysis showing a $120 \%$ return on investment [49]. The evaluation also documented two criticisms of the programme: the restricted capacity for training providers to find rural placements for trainees not on the pathway and the negative impact of the programme on private general practice $[49,50]$. Funded vocational RGM pathways now exist in other Australian states [26-28, 51, 52].

This degree of government administration, coordination and management of RGM programmes is unique to the Australian context. However, there are training programmes and agreements organised toward similar goals in other countries. Ethiopia's first training programme in family medicine was established in 2013 [12] with the aim of providing postgraduate training to develop comprehensive-care generalist doctors for underserviced urban and rural areas [12]. A collaboration between the Royal College of Physicians and Surgeons of Canada and the College of Family Physicians of Canada (CFPC) developed guidelines for surgical services delivered by family practitioners (FPs) in rural areas [53]. Similarly, a shortage of rural FP anaesthetists led to the development of accreditation standards which also applied to training of FP surgeons and FP obstetricians across rural Canada [54]. Additionally, there was a call to establish a college for rural medicine in Canada to specifically prepare rural generalists with specialised skills [55]. In 2008, the CFPC approved family physicians with special interests and accredited enhanced skills that met the Triple $\mathrm{C}$ curriculum standards ('continuing care centred' in family medicine) [56]. This was particularly relevant to rural FPs, where these skills were more commonly required [56].

\section{Scope of practice and service models}

Ideally, scope of practice is tailored to meet community needs and is responsive to a range of factors, including population size, demographics, burden of disease, access to specialist services, geography and socioeconomic status [42]. As the provision of primary health care is common to RGM internationally, the literature on scope of practice is largely focused on the additional, specialised skills provided.

The QRGP supports advanced skills training (AST) in adult internal medicine, Indigenous health, emergency medicine, paediatrics, mental health, obstetrics and gynaecology, anaesthetics and surgery [24]. The procedural skills listed here are common to the scope of practice in other states and territories across Australia and in New Zealand, 
in particular obstetrics and gynaecology, anaesthetics, emergency medicine and surgery [27, 28, 57, 58].

These procedural skills are also common to RGM in Canada and the USA [59, 60]. In Western European countries, the rural generalist undertakes some procedural tasks, especially in minor surgery [22]. In sub-Saharan Africa, obstetrics, anaesthetics and surgery are common skills for rural family physicians [61, 62]. In South Africa, the generalist in remote areas can also provide orthopaedic care and ENT practice [63, 64].

Whilst core procedural skills are a feature of RGM, there is also evidence of training in non-procedural tasks. The QRGP includes Indigenous health, paediatrics and mental health in the supported ASTs [24]. The Tasmanian Rural Medical Generalist Program has also identified needs in psychiatry, radiology and palliative care [51]. Palliative and elder care is also featured in Canadian RGM training [6, 65].

Discussion on scope of practice extends to models of care, including interaction between generalists and medical specialists, and the quality and safety of comprehensive care. In Canada, there is general agreement between specialist colleges that a generalist approach to procedural services in rural areas is the only feasible solution to rural medical workforce issues [66]. However, there is ongoing interprofessional debate between rural general practice and surgery about role delineation, despite it being uncommon for smaller communities to have surgical services provided by a resident specialist surgeon [66]. Kornelsen et al. (2013) claim that in communities with populations of 5000 to 15000 , surgical services are usually provided by one or more rural GP surgeons, whilst for populations of 15000 to 25000 surgical services are usually provided by a specialist surgeon supported by one or more GP surgeons [66]. Australian models of care are similar in that specialised skills practised by the rural generalist increase with complexity with less specialist support as rurality or remoteness increases [67]. In South Africa, there are two opposing views on the model of remote emergency care: (i) stabilisation and transportation of patients to a larger hospital and (ii) support local hospital services where the generalist can treat most cases [63].

The model of care where the generalist provides increasing specialist care proportional to remoteness is also supported by quality and safety outcomes [42]. In Canada, a study comparing caesarean section services provided by rural GPs with those of specialists concludes that rural GPs perform this procedure with an acceptable degree of safety [68]. Rural hospitals in Nova Scotia with less than 100 deliveries a year performed by rural generalists have also shown the lowest perinatal morbidity and mortality rates in the province [69]. Thompson and Iglesias (1998) conclude that there is no evidence to support exclusive skills sets given numerous quality and safety studies demonstrate identical standards for both rural generalists and urban specialists [55].

\section{Enablers and barriers to recruitment and retention}

The ability to be trained in, and then practice, specialised skills is considered essential in successful RGM recruitment and retention. The ability to combine procedural work with primary health care is key to much rural recruitment in the Australian context [52, 70]. This, combined with the commencing salary and financial incentives offered under the QRGP, have had a positive impact on rural medical workforce recruitment [49]. In the USA, training programmes producing rural generalist graduates also emphasise comprehensive advanced skills training as key to their success $[17,60]$. A study in Canada also showed the larger the range of procedures practised by a family physician, the more satisfied they were in their profession [71].

However, the trend of medical graduates toward highly specialised career choices and corresponding control of hospital-based training posts by specialists are considered threats to RGM in North America [32, 72] and Australia [73]. This also adversely affects the distribution of the overall medical workforce due to the urban-centric focus of speciality practice [73]. There are further systemic barriers for rural generalist practice in Australia, including a lack of appropriate training opportunities and support [74], complexities in maintaining and practising advanced skills, the limited availability of the supporting workforce, working hours and lifestyle factors, perceived medico-legal problems [75, 76], a lack of recognition for the rural generalist role and GPs' reluctance to resume procedural practice once they had ceased $[52,77]$.

In the USA, one article identified high liability insurance premiums as a threat to viable smaller rural generalist practices, as well as limited technical facilities and the lack of an appropriate support workforce [78]. In Canada, difficult access to locums, the need for more education and training [79], low confidence in responding to paediatric emergencies and worsening physician shortages [80] are seen as the major barriers to developing the rural generalist workforce. In Europe, the pressures of providing the dual-role of primary care practitioner and specialist in rural communities [81], as well as an increasing centralisation of specialist services to larger centres, are negatively affecting RGM [82]. As a result, fewer rural GPs are practising obstetrics in Europe and it is increasingly rare for those remaining to undertake high-risk obstetric care as routine practice [83].

\section{Reform recommendations}

The reform theme can be separated into recommendations from the literature that (i) are focused on training and (ii) have a broader workforce focus. 
In Australia, recommendations for training reform include: improving linkages between Commonwealth and State training programmes; increasing support for universities committed to rural generalism; identifying new advanced skills [84]; accelerated vocational pathways into RGM; training and supporting a rural female proceduralist workforce; extending the QRGP training model into other Australian states [85]; and establishing training support networks $[42,86,87]$. The concept of a national RGM training pipeline in Australia is common to many of the training recommendations [1, 74, 88, 89]. Similarly, a USA article supported the concept of a national rural training pipeline that recruits from rural communities, provides rural placements throughout medical school, supports residencies in the rural setting and provides support in rural practice after training [17].

In Canada, the Canadian Medical Association committed to expand the number of rural generalists in training [90] and the Society of Rural Physicians have proposed developing a national rural medicine curriculum to promote the RGM workforce [31]. Other Canadian-based proposals include the establishment of a college for rural medicine [55], an extra training year with focus on procedural and obstetric care skills for family practitioners intending to work rurally [91], expanding and improving enhanced skills training programmes aligned to community need [59, 90, 92] (including advanced maternity care [93], anaesthetics, general surgery [94] and endoscopy [55, 79]).

In Africa, recommendations include increasing the number of rural generalists in training and providing a more structured secondary-care curricula across a broad range of diagnoses and procedural skills [64], similar to Australia and Canada [61, 95]. In South Africa it is recommended that more generalists with specialised skills be trained to position them as the leading health professional in the District Health System [96].

There are also recommendations for new RGM training models in many countries. Recommendations in Kenya include expanding the scope of practice for rural generalists to include emergency surgery [97]. In Japan the authors of one article advocate for the establishment of a rural generalist practitioner training programme with specialised skills, including internal medicine, gastroenterology and general surgery [98].

The literature also contains recommendations for broader workforce policy reform. A New Zealand article outlines efforts made to recognise the RGM role as a specific discipline to advance RGM practice [58]. In Australia, such recommendations include new national funding models that support the RGM pathway [42], workforce strategies aimed at recruitment and retention of rural generalists [48], supporting flexible models of practice ownership [73] and developing a national approach to recognising the rural generalist role [89].
Many of these relate to the broader agenda to develop a national RGM pathway throughout Australia [1, 8, 85] and to establish a specific role in the Commonwealth Government dedicated to this task [25].

The Cairns Consensus Statement contains policy-based recommendations under the domains of 'Recognition, Training and Research' for global action in RGM [2]. This is complemented by an earlier WHO recommendation to establish and regulate enhanced scopes of practice (including for Family Medicine) in rural and remote areas [99].

\section{Discussion}

The effort to develop an internationally agreed definition of RGM and priorities for action through the Cairns Consensus Statement provides an opportunity to review global approaches relevant to RGM [2]. This is further underpinned by international health care planning, including the WHO Workforce 2030 Strategy, which aims to correct workforce supply, maldistribution and the imbalance of specialists to generalists [16].

This review found a significant body of literature relevant to the subject of RGM. However, the majority of this originates from Australia, New Zealand and North America (82 out of 102 articles). This reflects the relative maturity of, and funding allocated to, coordinated RGM programmes and pathways in these regions. The smaller volume of literature from lower-middle income countries and/or lesser developed programmes reflects a need for increasing research, support and evidence to evaluate and progress their RGM training pathways and programme design.

What literature was available from these lower income countries or those with less developed programmes does show the extent of emerging interest in RGM. Thigiti et al. (2011) describe the potential to expand the Kenyan 'Master of Family Medicine' training programme into Uganda and Rwanda [47] and the developing family physician role in Ethiopia, which will likely provide emergency surgical and obstetric services for those practising rurally [12]. The need for a role with procedural skills, especially in emergency medicine, obstetrics and fracture management, has also been identified in rural Nepal [100, 101], whilst in India, a trial to train rural Medical Officers in Life Saving Anaesthetic Skills was recommended for extension in response to a shortage of rural anaesthetists [102]. There are also some known early RGM programmes, including in Papua New Guinea and the Cook Islands, and some discussions occurring around RGM models in Fiji, Tonga and Zimbabwe. At the World Summit on Rural Generalist Medicine in 2017, Japan also launched its Rural Generalist programme.

This review also identified recommendations to coordinate national RGM pathways within Australia, Canada and the USA, which illustrates the need for ongoing 
improvements in countries where there are established programmes. Reflections on the literature identifying such improvements could also present valuable learnings for emerging programmes as they continue to build RGM models matched to local needs. Future research on commonalities and contextual differences between RGM programmes internationally (in both high and low income settings) could further understanding of best practice in RGM policy, training and delivery.

Descriptive opinion pieces were the most common form of article identified in this review (40 in total), highlighting the lack of high quality research evidence on RGM. This supports the need for more research to improve the quality of RGM-relevant data as programmes continue to develop internationally in response to ongoing rural health and health workforce needs.

\section{Conclusion}

Developing RGM training programmes and models of practice can be a key strategy in improving health care and outcomes in rural communities around the world. This review has synthesised literature relevant to RGM, its development and implementation internationally. Whilst the majority of articles originate from Australia, Canada and the USA, there is also literature emerging from countries such as Japan, Kenya, Uganda, Rwanda, Ethiopia and India. Efforts to coordinate and strengthen RGM pathways as a response to both workforce shortages and health needs in rural and remote areas internationally are now being shared through forums such as the biennial World Summit on Rural Generalist Medicine. Scale-up of high-quality research and publication of evidence related to RGM is now required to support best practice outcomes as this momentum continues to build.

\section{Abbreviations \\ ACRRM: Australian College of Rural and Remote Medicine; FP: Family practitioner; GP: General practitioner; QRGP: Queensland Rural Generalist Pathway; RGM: Rural generalist medicine; WHO: World Health Organization}

\section{Acknowledgements}

We would like to acknowledge Professor Jane Farmer and Professor Amanda Kenny for their initial support and advice in the drafting of this Scoping Review.

\section{Funding}

No funding has been sourced in the development of this research report.

\section{Availability of data and materials}

Original articles identified and scoping review materials available from authors on request.

\section{Authors' contributions}

NS analysed and interpreted the literature and drafted the manuscript. RE reviewed the included and excluded articles for accuracy. All authors contributed to editing and read and approved the final manuscript.

Ethics approval and consent to participate

Not applicable
Consent for publication

Not applicable

\section{Competing interests}

The authors declare that they have no competing interests.

\section{Publisher's Note}

Springer Nature remains neutral with regard to jurisdictional claims in published maps and institutional affiliations.

\section{Author details}

${ }^{1}$ James Cook University, Townsville, Australia. ${ }^{2}$ College of Medicine and Dentistry, James Cook University, Townsville, Australia. ${ }^{3} \mathrm{KBC}$, Orange, Australia. ${ }^{4}$ Rocketship Pacific Ltd, Geneva, Switzerland.

Received: 9 August 2018 Accepted: 7 November 2018

Published online: 21 November 2018

\section{References}

1. Health Workforce Australia: Rural Medical Generalist DRAFT National Framework. 2013.

2. Australian College of Rural and Remote Medicine. Cairns Consensus Statement on Rural Generalist Medicine: improved health for rural communities through accessible, high quality healthcare: Australian College of Rural and Remote Medicine; 2014.

3. Health Workforce Australia. National Rural and Remote Workforce Innovation and Reform Strategy: Australian Government; 2013.

4. Stratigos S, Nichols A. Procedural Rural Medicine: Strategies Towards Solutions. Rural Doctors Association of Australia, College of Rural and Remote Medicine; 2002.

5. Levack PA, Levack ID. Medical practice on Tristan da Cunha--the remotest island community in the world. J R Coll Physicians Edinb. 2013;43:290-3.

6. Imrie K, Weston W, Kennedy M. Generalism in postgraduate. Med Educ. 2011

7. Watt G. The inverse care law today. Lancet. 2002;360:252-4.

8. NOVA Public Policy P/L. Review of the Queensland Health Rural Generalist Pathway (RGP) model to examine whether there is the potential to expand the model nationally; 2010.

9. International Conferences [http://www.acrrm.org.au/about-the-college/ international/international-conferences]. Accessed 2015.

10. Duns G. Challenges and rewards--a career as a generalist. Aust Fam Physician. 2013:42:439.

11. Ono T, Schoenstein M, Buchan J. In: OECD Health Working Papers DfE, Labour and Social Affairs, Health Committee, editor. Geographic Imbalances in Doctor Supply and Policy Responses: OECD Publishing; 2014.

12. Philpott J, Cornelson B, Derbew M, Haq C, Kvach E, Mekasha A, Rouleau K, Tefera $G$, Wondimagegn D, Wilson L, Yigeremu M. The dawn of family medicine in Ethiopia. Fam Med. 2014;46:685-90.

13. Monjok E, Essien EJ, Smesny A, Okpokam SN. A training need for rural primary care in Nigeria. J Obstet Gynaecol. 2010;30:833-5.

14. Holst J. Rethinking medical training in Germany towards rural health care. Primary Health Care: Open Access. 2015;5:1-6.

15. Hussain R, Maple M, Hunter SV, Mapedzahama V, Reddy P. The Fly-in Fly-out and Drive-in and Drive-out model of health care service provision for rura and remote Australia: benefits and disadvantages. Rural Remote Health. 2015;15:1-7

16. World Health Organization: Global strategy on human resources for health: Workforce 2030. 2016

17. Hart G. Health care workforce supply in underserved rural areas of the United States. In 5th International Medical Workforce Conference. Sydney: National Rural Health Association, Washington DC; 2000.

18. de Klerk B. President's message. Generalism is dead: long live generalism. Can J Rural Med. 2013;18:121

19. Battye K, White C, Cronin S, Bond N, Mitchell C. Solutions to the provision of primary care to rural and remote communities in Queensland. Health Workforce Queensland; 2005.

20. Arksey H, O'Malley L. Scoping studies: towards a methodological framework Int J Soc Res Methodol. 2005;8:19-32.

21. Lyle DM, Barclay LM. Securing a rural health workforce for the next generation of rural Australians. MJA. 2015;1:469.

22. Boerma WGW, Groenewegen PP, Van Der Zee J. General Practice in urban and rural Europe: curative services. Soc Sci Med. 1998;47:445-53. 
23. Manahan D, Sen Gupta T, Lennox D, Taylor N, Rowan C, Hanson D, McKenzie A, Telfer J, Browning L. The rural generalist: a new generation of health professionals providing the rural medical workforce the bush needs. In: Proceedings of the 11th National Rural Health Conference; 2011.

24. Rural Generalist Pathway [https://ruralgeneralist.qld.gov.au/]. Accessed 2016.

25. Australian College of Rural and Remote Medicine. The Rural Way: implementation of a National Rural Generalist Pathway. Australian College of Rural and Remote Medicine; 2014.

26. Rural Generalist Training Program [http://www.heti.nsw.gov.au/rural-andremote/rural-generalist-training/]. Accessed 2016.

27. Rural Medical Generalist Pathways in the Northern Territory [https://health.nt.gov. au/careers]. Accessed 2016.

28. Rural Generalist Pathways Victoria. 2018. [https://www2.health.vic.gov.au/ health-workforce/medical-workforce-in-victoria/rural-medicalworkforce\#vgp].

29. The Collingrove Agreement [http://www.acrrm.org.au/rsrc/documents/misc/ the-collingrove-agreement.pdf]. Accessed 2018.

30. MacLellan K. Generalism and rural Canada. Can J Rural Med. 2006;11:177

31. de Klerk B. SRPC report on the first World Summit on Rural Generalist Medicine... Society of Rural Physicians of Canada. Can J Rural Med. 2014;19:34.

32. Williams PT. Twenty-year trends in the Ohio generalist physician workforce. J Fam Pract. 1998:47:434-9.

33. Williams PT, Whitcomb M, Harris R. Generalist physicians in nonmetropolitan counties in Ohio. Arch Fam Med. 1994;3:425-8.

34. Wartman SA, Wilson M, Kahn N. The generalist health care workforce: issues and goals. J Gen Intern Med. 1994;9:S7-13.

35. Colwill JM, Cultice M. The future supply of family physicians: implications for rural America. Health Affairs. 2003;22:190-8.

36. Handford $\mathrm{C}$, Hennen $\mathrm{B}$. The gentle radical: ten reflections on lan McWhinney, generalism, and family medicine today. Can Fam Physician. 2014;60:20-3.

37. Baugh J, Harmon GE, Bosscher DB, Averill WC, Glazer JL. Saving generalist medicine... Dr. James Glazer's editorial "Specialization in family medicine education: abandoning our generalist roots" (February 2007). Fam Pract Manag. 2007;14:11-2.

38. Lee $\mathrm{KH}$. A historical perspective of the barriers to generalism. Aust Fam Physician. 2015;44:154-8.

39. Lawrance R. NRF: rural generalism or rural general practice? Aust J Rural Health. 2007;15:391-3.

40. Sen Gupta T, Murray R, Hays R, Woolley T. James Cook University MBBS graduate intentions and intern destinations: a comparative study with other Queensland and Australian medical schools. Rural Remote Health. 2013;13:1-10.

41. Worley P, Silagy C, Prideaux D, Newble D, Jones A. The parallel rural community curriculum: an integrated clinical curriculum based in rural general practice. Med Educ. 2000;34:558-65.

42. Pashen D, Murray R, Chater B, Sheedy V, White C, Eriksson L, De La Rue S, Du Rietz M. The expanding role of the rural generalist in Australia - a systematic review. Brisbane: Australian College of Rural and Remote Medicine; 2007.

43. Greenhill JA, Walker J, Playford D. Outcomes of Australian rural clinical schools: a decade of success building the rural medical workforce through the education and training continuum. Rural Remote Health. 2015;15:2991.

44. Crutcher RA, Szafran O, Woloschuk W, Chaytors RG, Topps DA, Humphries PWA, Norton PG. Where Canadian Family Physicians Learn Procedural Skills. Residency Education. 2005;37:491-5.

45. Ramsey PG, Coombs JB, Hunt DD, Marshall SG, Wenrich MD. From concept to culture: the WWAMI program at the University of Washington School of Medicine. Acad Med. 2001;76:765-75.

46. Maudlin RK, Newkirk GR. Family Medicine Spokane Rural Training Track: 24 years of rural-based graduate medical education. Fam Med. 2010;42:723-8.

47. Thigiti J, Heres W, Van Den Hombergh P, Jurgens E, Wendte H. Human resources for health crises in rural Africa: the contribution of family medicine in providing answers. Trop Med Int Health. 2011;16:41.

48. Sen Gupta TK, Manahan DL, Lennox DR, Taylor NL. The Queensland Health Rural Generalist Pathway: providing a medical workforce for the bush. Rural \& Remote Health. 2013;13:1-10.

49. Ernst \& Young. Evaluation and Investigative Study of the Queensland Rural Generalist Program: Queensland Health, Office of Rural and Remote Health; 2013.

50. Kitchener S. Rural Generalism and the Queensland Health pathway implications for rural clinical supervisors, placements and rural medical education providers. Rural \& Remote Health. 2013;13:1-7.
51. The Tasmanian Rural Medical Generalist Pathway Program [http://www.dhhs tas.gov.au/career/home/medical/junior_docs/more_information_-_north_ west_area_health_service/rural_medical_generalist_pathway]. Accessed 2016.

52. Rural Health West. Finding My Place: Factors Influencing the Attraction and Retention of Doctors in Rural Western Australia. In Feedback from Rural Doctors, vol. 1. Rural Health West; 2015.

53. Inglis FG. Surgical care in rural Canada: training and planning for the future. Can Med Assoc J. 1995;15:1453-4.

54. Lockyer J, Norton P. An analysis of the development of a successful medical collaboration to create and sustain family physician anaesthesiology capacity in rural Canada. Aust J Rural Health. 2005;13:178-82.

55. Thompson J, Iglesias S. Shared skill sets: a model for the training and accreditation of rural advanced skills. Can J Rural Med. 1998:3:217-22.

56. Gutkin C. Focusing on generalism. Can Fam Physician. 2012;58:351-2.

57. Pereria G. Rural generalist. Aust Fam Physician. 2010;39:459.

58. Nixon G, Blattner K, Dawson J, Fearnley D, Gardiner S, Hoskin S, Kashyap B, Naicker K, Nieuwoudt B, Skinner A, et al. Rural hospital medicine in New Zealand: Vocational registration and the recognition of a new scope of practice. N Z Med J. 2007;120:1-5.

59. Soles J. President's message. Rural generalism. Can J Rural Med. 2015;20:5.

60. Geyman JP, Hart LG, Norris TE, Coombs JB, Lishner DM. Educating generalist physicians for rural practice: how are we doing? J Rural Health. 2000;16:56-80.

61. Reid SJ, Mash R, Downing RV, Moosa S. Perspectives on key principles of generalist medical practice in public service in sub-Saharan Africa: a qualitative study. BMC Fam Pract. 2011;12:67.

62. Reid SJ, Chabikuli N, Jaques PH, Fehrsen GS. The procedural skills of rural hospital doctors. S Afr Med J. 1999;89:769-74.

63. Ellis $C$. Training general practitioners for very remote areas. Med Teach. 2008;30:809-11.

64. Hill PV. Procedural skills in rural practice - a practice profile. S Afr Fam Pract. 1995;16:674-7.

65. Jones FR. Generalists rule OK! 2014

66. Kornelsen J, Iglesias S, Humber N, Caron N, Grzybowski S. The Experience of GP Surgeons in Western Canada: The Influence of Interprofessional Relationships in Training and Practice. Journal of Research in Interprofessional Practice and Education. 2013:3:43-61.

67. Humphreys JS, Jones JA, Jones MP, Mildenhall D, P.R. M, Chater B, Rosenthal DR, Maxfield NM, Adena MA. The influence of geographical location on the complexity of rural general practice activities. MJA. 2003;179:416-20.

68. Aubrey-Bassler K, Newbery S, Kelly L, Weaver B, Wilson S. Maternal outcomes of cesarean sections: do generalists' patients have different outcomes than specialists' patients? Can Fam Physician. 2007;53:2132-8.

69. Hutten-Czapski P. Life on Mars: practising obstetrics without an obstetrician [Editorial]. Can J Rural Med. 1998;3:69.

70. Tolhurst HM, Adams J, Stewart SM. An exploration of when urban background medical students become interested in rural practice. Rural Remote Health. 2006:6:452.

71. Rivet C, Ryan B, Stewart M. Hands On: Is there an asociation between doing procedures and job satisfaction? Can Fam Physician. 2007:53:92-93.e5

72. Urbina C, Hickey M, McHarney-Brown C, Duban S, Kaufman A. Innovative generalist programs: academic health care centers respond to the shortage of generalist physicians. J Gen Intern Med. 1994;9:S81-9.

73. Larkins S, Evans R. Greater support for generalism in rural and regional Australia. Aust Fam Physician. 2014;43:487-90.

74. Murdoch J, Denz-Penhey H. John Flynn meets James Mackenzie: developing the discipline of rural and remote medicine in Australia. Rural Remote Health. 2007;7:726.

75. Glazebrook RM, Harrison SL. Obstacles to maintenance of advanced procedural skills for rural and remote medical practitioners in Australia. Rural Remote Health. 2006:6:1-14.

76. Australian College of Rural and Remote Medicine. Barriers to the maintenance of procedural skills in rural and remote medicine and Factors influencing the relocation of rural proceduralists. In ACRRM Research Projects. Australian College of Rural and Remote Medicine; 2002

77. Health Workforce Australia: The GP proceduralist (maternity services) workforce in rural Victoria: future demand analysis; 2014.

78. Bronstein JM. Entrance and exit of obstetrics providers in rural Alabama. J Rural Health. 1992:8:114-20

79. Angle P, Kurtz Landy C, Murthy Y, Cino P. Key issues and barriers to obstetrical anesthesia care in Ontario community hospitals with fewer than 2,000 deliveries annually. Can J Anesth. 2009;56:667-77. 
80. Lew E, Fagnan L, Mattek N, Mahler J, Lowe RA. Emergency Department Coverage by Primary Care Physicians in a Rural Practice-Based Research Network: Incentives, Confidence and Training. J Rural Health. 2009;25:189-93.

81. Iversen L, Farmer JC, Hannaford PC. Workload pressures in rural general practice: a qualitative investigation. Scand J Prim Health Care. 2002;20:139-44.

82. Tucker J, Hundley V, Kiger A, Bryers H, Caldow J, Farmer J, Harris F, Ireland J, van Teijlingen E. Sustainable maternity services in remote and rural Scotland? A qualitative survey of staff views on required skills, competencies and training. Qual Saf Health Care. 2005;14:34-40.

83. Wiegers TA. General practitioners and their role in maternity care. Health Policy. 2003;66:51.

84. Ellis IK, Philip T. Improving the skills of rural and remote generalists to manage mental health emergencies. Rural Remote Health. 2010;10:1503.

85. Senate Community Affairs Committee Secretariat. In: Australia Co, editor The factors affecting the supply of health services and medical professionals in rural areas. Canberra: Senate Printing Unit, Parliament House; 2012.

86. Australian College of Rural and Remote Medicine. Training and support for procedural practice in rural and remote medicine: solutions paper: Australian College of Rural and Remote Medicine; 2002.

87. Murray RB, Wronski I. When the tide goes out: health workforce in rural, remote and indigenous communities. Med J Australia. 2006;185:37-8.

88. Mason J. Review of Australian government health workforce programs; 2013.

89. Rural Doctors Association of Australia: A national advanced rural training program: discussion paper. 2012.

90. Jong M. President's message: Need for a national rural health strategy. Can J Rural Med. 2007;12:205

91. Gordon Chaytors R, Szafran O, Crutcher RA. Rural-Urban and Gender Difference in Procedures Performed by Family Practice Residency Graduates. Fam Med. 2001;33:766-71.

92. Wootton J. Who will provide secondary care in rural Canada? Can J Rural Med. 2007;12:67

93. Miller KJ, Couchie C, Ehman W, Graves L, Grzybowski S, Medves J. Rural maternity care. J Obstet Gynaecol Can. 2012;34:984-1000.

94. Oberai A, Solomon A, Kassaye E, Kebede B. Learning from our Ethiopian colleagues: operative obstetrics for the generalist. Can J Rural Med. 2014;19:108-10.

95. Howe AC, Mash RJ, Hugo JF. Developing generalism in the South African context. S Afr Med J. 2013;103:899-900.

96. de Villiers PJT, Editor in Chief: Family medicine as a new specialty in South Africa. South Afr Fam Pract 2004, 46:3.

97. Downing J. To the Editor. African Family Medicine. 2008:10.

98. Matsumoto M, Obayama M, Inoue K, Kajii E. Factors associated with rural doctors' intention to continue a rural career: a survey of 3072 doctors in Japan. Aust J Rural Health. 2005;13:219-25.

99. World Health Organizatio. Increasing access to health workers in remote and rural areas through improved retention. In Global policy recommendations. WHO Press: World Health Organization; 2010.

100. Moore M. Opportunities and challenges for GPs in the developing world. Aust Fam Physician. 2006;35:531-2.

101. Basnyat A. Primary care in a rural set up in Nepal: perspectives of a generalist. J Family Med Prim Care. 2013;2:218-21.

102. Mavalankar D, Callahan $K$, Sriram V, Singh $P$, Desai A. Where there is no anesthetist - increasing capacity for emergency obstetric care in rural India: an evaluation of a pilot program to train general doctors. Int J Gynecol Obstet. 2009:107:283-8.

103. Australian College of Rural and Remote Medicine. Hobart symposium: procedural rural medicine recommendations: ACRRM; 2002.

104. Australian Medical Association. Position statement: fostering generalism in the medical workforce: AMA; 2012

105. Regional Training Networks [https://ama.com.au/position-statement/ regional-training-networks-2014]. Accessed 2014

106. Carson PJ. Providing specialist services in Australia across barriers of distance and culture. World J Surg. 2009;33:1562-7.

107. Road to Rural GP Program [http://www.sahealthcareers.com.au/campaign. php?id=99]. Accessed 2016

108. Hays RB, Veitch C, Evans RJ. The determinants of quality in procedural rural medical care. Rural Remote Health. 2005:5:473.

109. Health Workforce Australia. Health Workforce 2025 - Doctors, Nurses and Midwives. vol. 1. Australian Government; 2012
110. McKenzie A, Beaton N, Hollins J, Jukka C, Hollins A. Advanced rural skills training: are recently qualified GPs using their procedural skills? Rural Remote Health. 2013;13:2159.

111. Sen Gupta TK, Manahan DL, Lennox DR, Taylor NL. Comment on: Rural Generalism and the Queensland Health pathway--implications for rural clinical supervisors, placements and rural medical education providers... Kitchener S. Rural Generalism and the Queensland Health pathway implications for rural clinical supervisors, placements and rural medical education providers. (RURAL REMOTE HEALTH), 2013 Apr-Jun; 13 (2): 1-7. Rural \& Remote Health. 2013;13:1-2.

112. Sondergeld S, Nicholas A. Rural Proceduralists: an endangered species. Report of the Queensland rural indemnity study, 1997. Aust J Rural Health 1998;6:126-31

113. Wainer J. Work of female rural doctors. Aust J Rural Health. 2004;12:49-53.

114. Avery G, Boyd J, Ruddiman A, Woollard R. Provincial Privileging Standards Project. MBC Medical Journal. 2014;56:326-7.

115. Baker E, Schmitz D, Epperly T, Nukui A, Moffat Miller C. Rural Idaho family physicians' scope of practice. J Rural Health. 2010;26:85-9.

116. Evans DV, Cole AM, Norris TE. Colonoscopy in rural communities: a systematic review of the frequency and quality. Rural Remote Health. 2015; 15:3057.

117. Hutten-Czapski P. Attacking generalism: using numbers when your argument is weak. Can J Rural Med. 2015;20:3-3.

118. Iglesias S, Hutten-Czapski P. Joint position paper on training for rural family practitioners in advanced maternity skills and cesarean section. Can J Rural Health. 1999:4:209-6.

119. Meyer GS, Cheng EY, Elting J. Differences between generalists and specialists in characteristics of patients receiving gastrointestinal procedures. J Gen Intern Med. 2000;15:188-94.

120. Sisler JJ, DeCarolis M, Robinson D, Sivananthan G. Family physicians who have focused practices in oncology: results of a national survey. Can Fam Physician. 2013;59:e290-7.

121. Wetmore SJ, Rivet C, Tepper J, Tatemichi S, Donoff M, Rainsberry P. Defining core procedure skills for Canadian family medicine training. Can Fam Physician. 2005:51:1364-5.

\section{Ready to submit your research? Choose BMC and benefit from:}

- fast, convenient online submission

- thorough peer review by experienced researchers in your field

- rapid publication on acceptance

- support for research data, including large and complex data types

- gold Open Access which fosters wider collaboration and increased citations

- maximum visibility for your research: over $100 \mathrm{M}$ website views per year

At $\mathrm{BMC}$, research is always in progress.

Learn more biomedcentral.com/submissions 